
WATER RESOURCES OF THE BIG SIOUX RIVER VALLEY NEAR SIOUX FALLS, SOUTH DAKOTA 


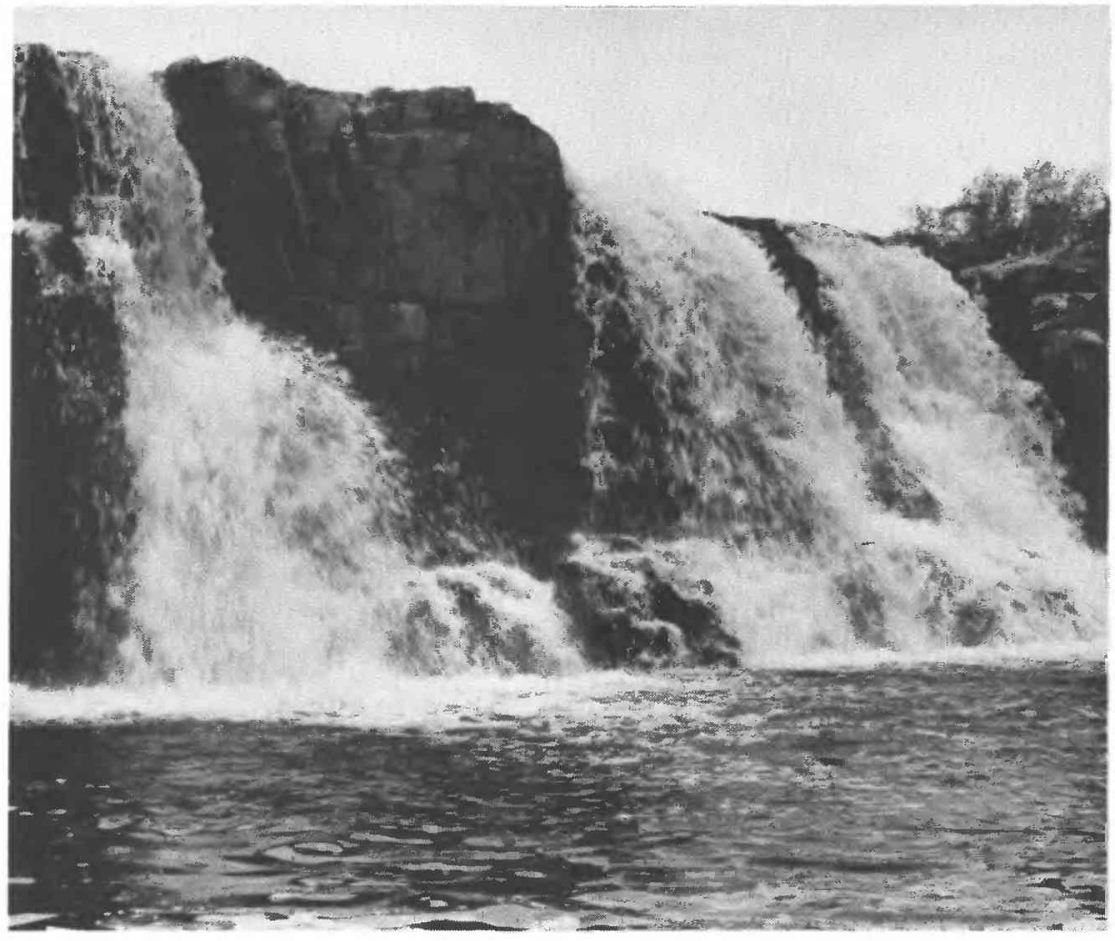

The falls of the Big Sioux River at Sioux Falls. 


\section{Water Resources of the}

Big Sioux River Valley

Near Sioux Falls,

South Dakota

By DONALD G. JORGENSEN and EARL A. ACKROYD

GEOLOGICAL SURVEY WATER-SUPPLY PAPER 2024

Prepared in cooperation with the

East Dakota Conservancy Subdistrict

and the city of Sioux Falls, South Dakota

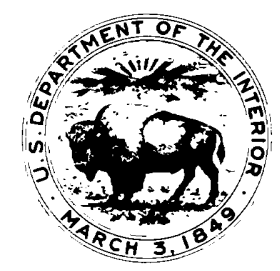

UNITED STATES GONERNMENI PRINING; OHFIC, WISHINGION: I973 
UNITED STATES DEPARTMENT OF THE INTERIOR

ROGERS C. B. MORTON, Secretary

\section{GEOLOGICAL SURVEY}

V. E. McKelvey, Director

Library of Congress catalog-card No. 73-600163

For sale by the Superintendent of Documents, U.S. Government Printing Office Washington, D.C. 20402 - Price $\$ 2.05$ (paper cover)

Stock Number 2401-02413 


\section{CONTENTS}

Abstract --1-.--

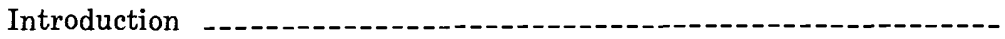

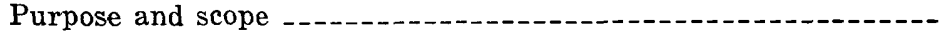

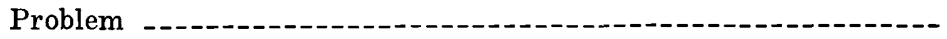

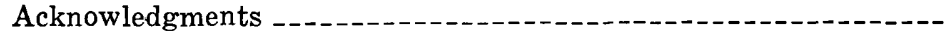

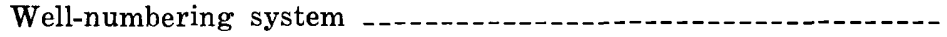

The hydrologic system -..-_-

The stream -

Character of the stream -..-_- 9

Occurrence of flow -

The aquifer -

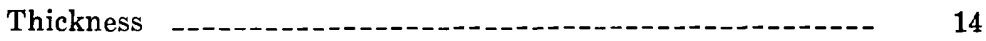

Hydraulic conductivity and transmissivity -_-_-_-..-- 14

Surface-water and ground-water relationship --_-_-_------- 15

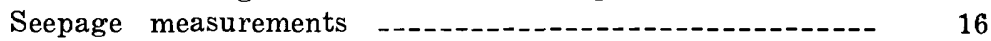

Aquifer pumping tests - -

Sampling of the diversion channel _.....-. 19

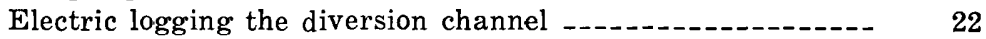

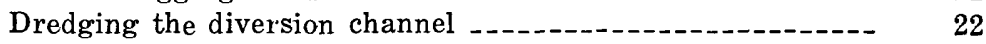

The analog model -

Electric analog modeling -

Description of model

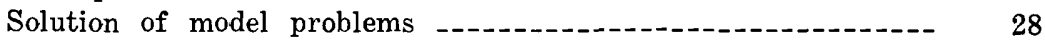

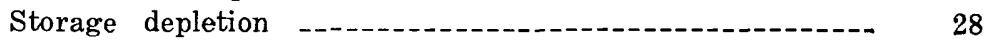

Fifteen million gallons per day pumping ---.---------- 29

Eighteen million gallons per day pumping -------------- 33

Maximum average daily pumping -..-_-_-_-_- 33

The digital model -

Solution of model problems --- 36

Storage depletion - -

Quality of water -

Measurements of conductivity and temperature -..-_-_-_-_-_-. 41

Chemical constituents of ground water and surface water ...-- 44

Summary -

Selected references -

\section{ILLUSTRATIONS}

Plate 1. Hydrologic maps of the Bix Sioux River valley near

Sioux Falls, S. Dak

Frontispiece. Photograph of the falls of the Big Sioux River at

Sioux Falls. 
2. Map of Sioux Falls well field, January 1, 1969 ...

3. Graph showing amount of water pumped by the city of Sioux Falls, 1908-68

4. Diagram of well-numbering system

5. Flow-duration curve showing frequency of daily discharges of the Big Sioux River near Dell Rapids_

6. Seasonal duration curve showing probability of flow for indicated intervals during the year in the Big Sioux River near Dell Rapids

7. Low-flow frequency curve showing the magnitude and frequency of minimum average consecutiveday discharges of the Big Sioux River near Dell Rapids

8. Flood-frequency curve showing peak discharges of the Big Sioux River near Dell Rapids

9. Map showing locations of discharge-measurement sites used to determine loss or gain of water in the Big Sioux River

10. Map showing location of dam, weir, and diversionchannel area

11. Profile of the diversion channel at station $144+00$

12. Hydrograph of the water-level rise resulting from dredging of sediment from the diversion channel.

13. Photograph of analog model of the area studied..--

14. Sketches of finite-difference grid, resistor-capacitor nets for modeling a pumping well, resistor-capacitor net and current-limiting diode for modeling streambed, and schematic diagram of analog model and operating components .............

15. Flow rates used for the analog-model solution of the storage-depletion problem

16. Graph showing analog-model solution of water-flow rates for average daily pumping of 15 million gallons per day

17. Graph showing analog-model solution of water-flow rates for average daily pumping of 18 million gallons per day

18. Graph showing analog-model solution of water-flow rates for average daily pumping of 24 million gallons per day

19. Map showing electrical conductivity of the water in the Sioux Falls well field, August 30, 1968

20. Graph of electrical conductivity of the water in the Big Sioux River and in wells 11 and 20 during 1968

21. Map of temperature of the water in the Sioux Falls well field, August 30, 1968

22. Graph of temperature of the water in the Big Sioux River and in wells 11 and 20 during 1968 
1. Estimates of population and water use for the city of Sioux Falls

Page

2. Monthly mean discharge of Big Sioux River near Dell Rapids, February 1958-January 1960

3. Discharges of the Big Sioux River used to determine loss or gain of streamflow

4. Water use by month for the city of Sioux Falls ....

5. Significance for domestic use of common chemical constitutents and physical properties of water --

6. Chemical analyses of water from the vicinity of the Sioux Falls well field 


\title{
WATER RESOURCES OF THE BIG SIOUX RIVER VALLEY NEAR SIOUX FALLS, SOUTH DAKOTA
}

\author{
By Donald G. Jorgensen and Earl A. Ackroyd
}

\section{ABSTRACT}

The major sources of water in the Big Sioux River valley between Sioux Falls and Dell Rapids, S.Dak., are the Big Sioux River and the glacial outwash aquifer beneath the flood plain. The river and the aquifer are hydraulically connected.

The Big Sioux River has an average annual discharge of 246 cubic feet per second, on the average exceeds bankfull stage every 2.3 years, and has moderate basin storage. Periods of low flow are common in the late summer, fall, and winter. A low flow of 0.1 cubic foot per second has been recorded.

The outwash aquifer is composed of permeable sand, sand and gravel, and some boulders. The aquifer underlies an area of 33 square miles and commonly has a saturated thickness of less than 30 feet.

Aquifer tests and measurements of streamflow indicate a rate of streambed infiltration of about 6 gallons per day per square foot. Analyses of streambed samples and interpretations of lithology from an electric log indicate that the streambed sediments in the diversion channel of the Big Sioux River consist largely of relatively impermeable silts and clays.

Under normal climatic conditions, most of the water pumped by the city of Sioux Falls is water that entered the aquifer by streambed infiltration.

To evaluate the importance of the aquifer in the hydrologic system, both an electrical analog model and a digital model were programed for storage depletion alone. These models were used to determine the water-level declines in the aquifer that would result from 1 year of withdrawal at a rate of 9-10 million gallons per day. Both models indicated that the existing well field can yield water at that rate for more than 1 year.

The analog model was also used to determine the maximum average daily yield of the aquifer-river system for a 2-year period modeled for the minimum recorded stream discharge and for streambed infiltration as the only recharge. The maximum average yield under these conditions would be less than 24 million gallons per day. Most of the water pumped during this period would be from aquifer storage.

Water from the river is generally less mineralized, softer, and easier to treat than ground water. Water pumped from wells near the river is similar in quality to the river water, but does not have the objectionable odors or tastes often present in water from the river. 


\section{INTRODUCTION}

\section{PURPOSE AND SCOPE}

The purpose of this report is to describe the effect of the development of a ground-water supply from the large, shallow aquifer in the Big Sioux River valley between Dell Rapids and Sioux Falls, S.Dak. A secondary purpose is to summarize the findings of previous water-supply investigations.

Although there are other aquifers in the area, such as sand lenses in the till and the fractured upper surface of the Sioux Quartzite, they are not major sources of water in the area. Therefore, in this report, the glacial outwash aquifer in the Big Sioux River valley between Dell Rapids and Sioux Falls will be referred to as the aquifer.

The investigation was conducted by the U.S. Geological Survey, in cooperation with the city of "Sioux Falls and the East Dakota Conservancy Subdistrict. In addition to this study, the U.S. Army Corps of Engineers and the U.S. Bureau of Reclamation, are evaluating the available water resources near the study area. In particular, the U.S. Army Corps of Engineers is evaluating a proposed damsite on Skunk Creek near Hartford and a proposed damsite 17 miles north of the study area on the Big Sioux River near Flandreau. The U.S. Bureau of Reclamation (1969) has finished a reconnaissance report on the feasibility of a reservoir on Slip Up Creek. (See fig. 1.)

The study consisted of the five major segments listed below:

1. Summarize existing data and investigations.

2. Define the hydrologic system, especially the areal extent of the aquifer and the relationship between the Big Sioux River and the aquifer.

3. Model the hydrologic system using electrical analog techniques and evaluate various plans of water-resources development.

4. Model the hydrologic system using digital modeling techniques as a means of evaluating the results obtained from the ana$\log$ model.

5. Define the quality of the water in the hydrologic system and its effect on development of the water resources.

Results of parts of this investigation have been described in short papers for the South Dakota Academy of Science. Ackroyd (1967) outlined the components of an analog computer needed to model the hydrologic system at Sioux Falls. Vaughan and Ackroyd (1968) reported the discovery of an aquifer at Sioux Falls that underlies the larger aquifer described in this report. Ackroyd 


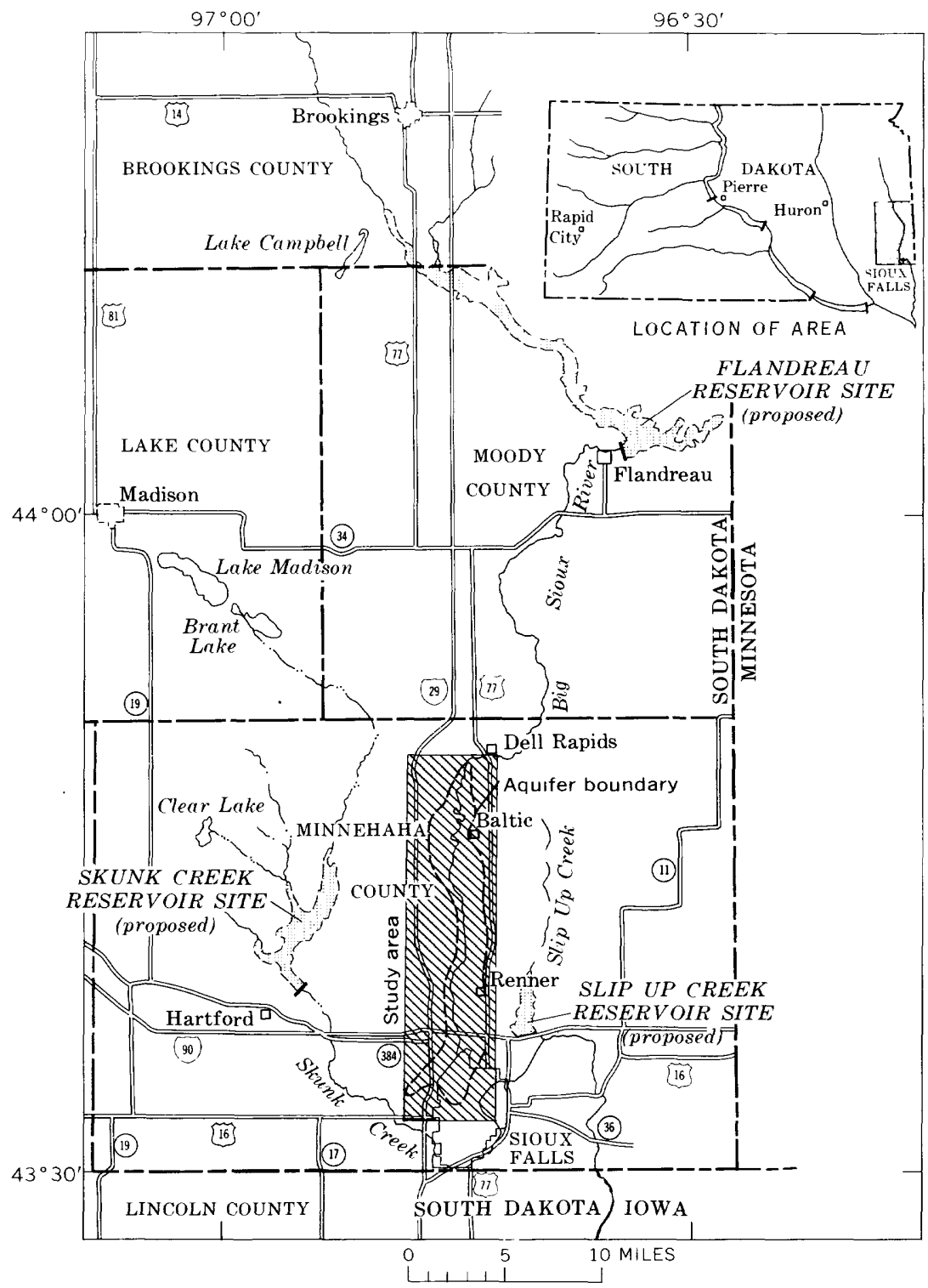

Figure 1.-The Sioux Falls area.

(1969) described the relationship between the Big Sioux River and the aquifer between Dell Rapids and Sioux Falls.

Reports of previous investigations that are relevant to this study include those of Rothrock and Otton (1947), who studied the geology and the ground-water resources of the Sioux Falls 
area; Steece (1959) who mapped the geology of the Sioux Falls quadrangle; and Tipton (1959), who mapped the geology of the Dell Rapids quadrangle. Both the basic-hydrologic-data report by Ellis (1968) and the corresponding hydrologic report by Ellis, Adolphson, and West (1969) contain information about the Big Sioux drainage basin. In addition several engineering reports by the U.S. Army Corps of Engineers, U.S. Bureau of Reclamation, and the consulting engineering firm, Greeley and Hanson, contain important data concerning the water resources of the area.

\section{PROBLEM}

The major water-resources problem treated in this report is to determine the maximum sustainable yield of the aquifer.

Since 1890 the residents of Sioux Falls have used wells in the present (1969) well-field area for their water supply. The number of wells and the amount of water withdrawn have increased rapidly as the population has increased. As of January 1, 1969, the city well field consisted of 28 operating wells. In addition to the water supply from wells, $6 \mathrm{mgd}$ (million gallons per day) of Big Sioux River water can be withdrawn directly from intakes in the flood-diversion channel. The locations of the wells and the surfacewater intakes (DC I and DC II) are shown in figure 2.

The regulation of river flow and pool elevation are controlled by a gated dam on the Big Sioux River and by a fixed-elevation weir in the diversion channel; both were built in 1961 by the U.S. Army Corps of Engineers. (See fig. 2.)

The average daily pumping rate is the total water pumped during the year divided by the number of days in the year. The maximum-day pumping rate is the pumping rate for the day during the year when the most water is pumped. As shown in figure 3 the maximum-day pumping rate for Sioux Falls is increasing slightly faster than the average daily pumping rate. The maximum pumping capacity of all the operating wells in the Sioux Falls well field as of January 1, 1969, was $27 \mathrm{mgd}$. This figure, which has not actually been attained, can be considered the maximumday pumping rate for the well field.

The maximum rate of water treatment as of January 1, 1969, was $26.3 \mathrm{mgd}$. The city of Sioux Falls is now implementing plans to increase the rate of treatment.

Sioux Falls is not the only water user in the area. The towns of Renner and Baltic, the rural residents in the area, and the residents of an unincorporated urban area north of Sioux Falls, also use water from the aquifer. In addition, water rights for irriga- 


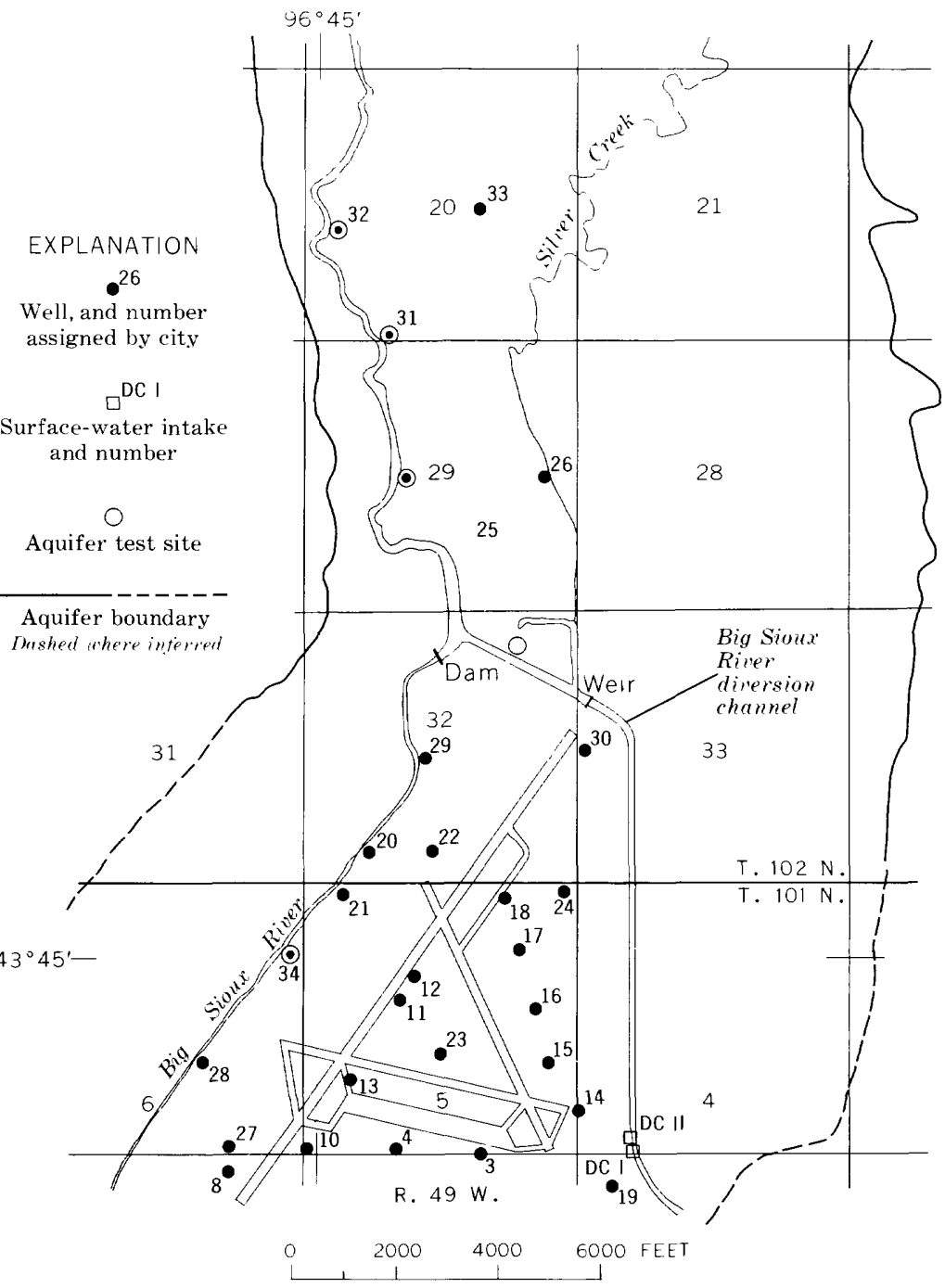

Figure 2.-Sioux Falls well field, January 1, 1969.

tion water from the aquifer have been granted for a total withdrawal rate of $8.5 \mathrm{mgd}$.

Many estimates have been made of the future water demand on the basis of anticipated population and industrial growth. A summary of the estimates is given in table 1 . All estimates indicate that much larger amounts of water will be needed by the city.

Because the maximum-day rate is rapidly approaching the 
BIG SIOUX RIVER VALLEY, SOUTH DAKOTA

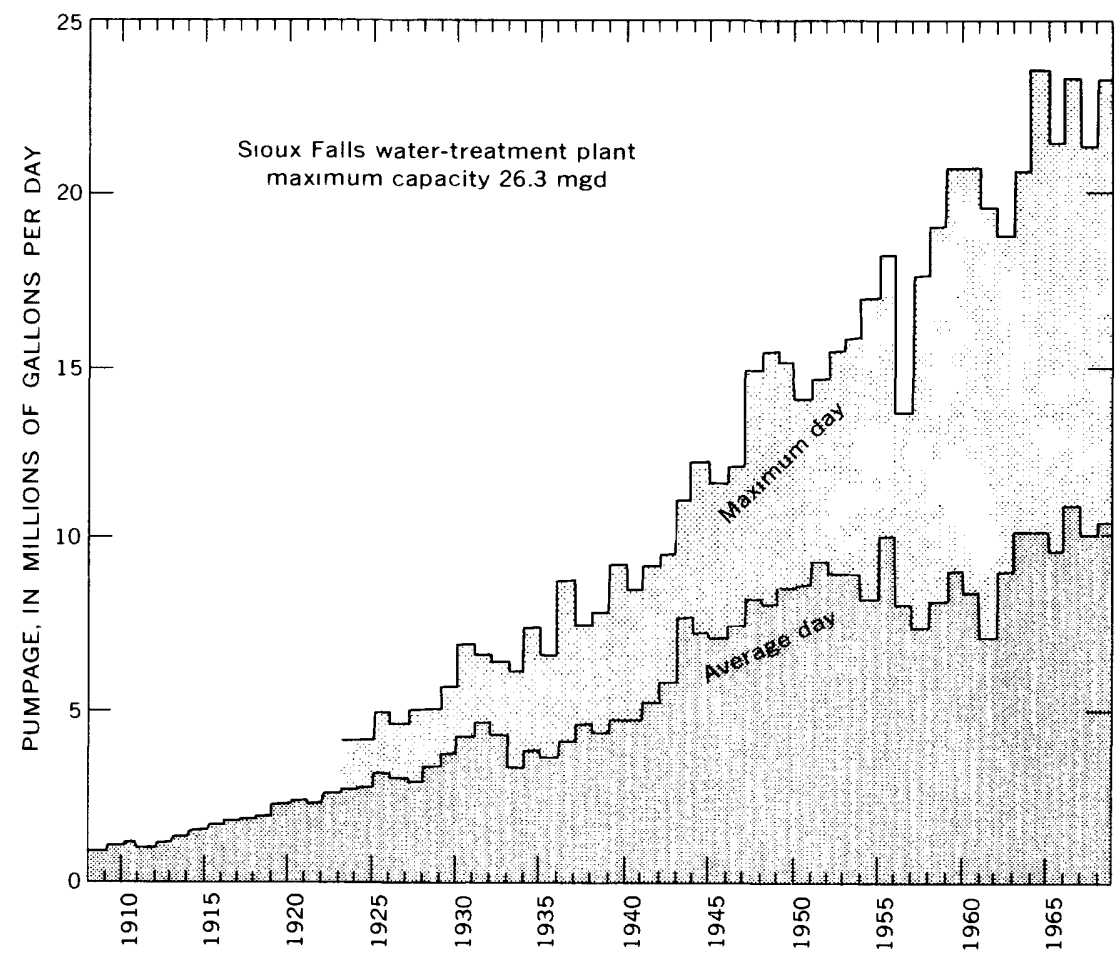

Frgure 3.-Water pumped by the city of Sioux Falls, 1908-68.

maximum-day capacity of the treatment plant and because estimates show increased demands for water in the future, expansion of the water supply and water-treatment facilities will be needed in the near future.

TABLE 1.-Estimates of population and water use for the city of Sioux Falls [Source of data: 1, Greeley and Hanson; 2, Corps of Engineers; 3, U.S. Bureau of Reclamation]

\begin{tabular}{|c|c|c|c|c|c|c|c|c|c|}
\hline \multirow{3}{*}{ Year } & & i & & \multicolumn{6}{|c|}{ Water use (mgd) } \\
\hline & \multicolumn{3}{|c|}{ Population } & \multicolumn{3}{|c|}{ Average day } & \multicolumn{3}{|c|}{ Maximum day } \\
\hline & 1 & 2 & 3 & 1 & 2 & 3 & 1 & 2 & 3 \\
\hline $\begin{array}{l}1980 \ldots \\
2000 \\
2020\end{array}$ & $\begin{array}{l}85,000 \\
95,000 \\
-\end{array}$ & $\begin{array}{r}1115,000 \\
1152,000 \\
1191,000\end{array}$ & $\begin{array}{l}112,000 \\
1 \in 0,000 \\
220,000\end{array}$ & $\begin{array}{r}15.0 \\
17.8 \\
-.-\end{array}$ & $\begin{array}{l}18.4 \\
29.0 \\
42.6\end{array}$ & $\begin{array}{l}30.4 \\
41.7\end{array}$ & $\begin{array}{r}31.5 \\
42.8 \\
---\end{array}$ & $\begin{array}{r}246.0 \\
294.3 \\
2170.4\end{array}$ & $\begin{array}{l}68.5 \\
93.8\end{array}$ \\
\hline
\end{tabular}

${ }^{1}$ Minnehaha County.

2 Maximum anticipated with heavy industrialization. 


\section{ACKNOWLEDGMENTS}

The cooperation and aid of Mr. Earl McCart, Sioux Falls Commissioner, and Mr. Vern Butler, Manager-Engineer, East Dakota Conservancy Subdistrict, contributed to the successful completion of the project.

The authors wish to acknowledge the assistance given by the Sioux Falls Water Treatment Department employees, especially Mr. Stanley Anderson. Mr. Kenneth Vaughan, engineer for the city of Sioux Falls, collected and analyzed water-quality data.

The analog model was built in the U.S. Geological Survey offices, Phoenix, Ariz., under the general supervision of Eugene Patten and the immediate direction of William Bruns.

A. Ivan Johnson, Staff Hydrologist, U.S. Geological Survey, planned the program of streambed-sediment sample collection and analyses.

Advice and aid in using the digital model of the Sioux Falls aquifer was given by Richard Lucky, of the U.S. Geological Survey.

\section{WELL-NUMBERING SYSTEM}

The locations of wells, test holes, and other sites are described by the system shown in figure 4 . The first numeral indicates the township, the second the range, and the third the section in which the well, test hole, or other site is located. The lowercase letters following the section number indicate the position of the well in the section. The first letter denotes the quarter section, the second letter the quarter-quarter section, the third letter the quarterquarter-quarter section. The subdivisions of a section are lettered $a, b, c$, and $d$ in a counterclockwise direction, starting in the northeast quarter. Thus, well 101-49-22dad, which is shown in figure 4 , is in the $\mathrm{SE}_{1 / 4} \mathrm{NE}_{1 / 4} \mathrm{SE} 1 / 4$ of sec. 22 , T. $101 \mathrm{~N}$., R. $49 \mathrm{~W}$.

\section{THE HYDROLOGIC SYSTEM}

Water moves continuously in a system called the hydrologic cycle. It falls from the atmosphere as precipitation to the earth where it runs off in streams such as the Big Sioux River, or it may infiltrate the ground and recharge an aquifer such as the one described in this report. Water may return to the atmosphere at nearly any point in the cycle. For example, surface water in the river may be lost by evaporation into the atmosphere, or 


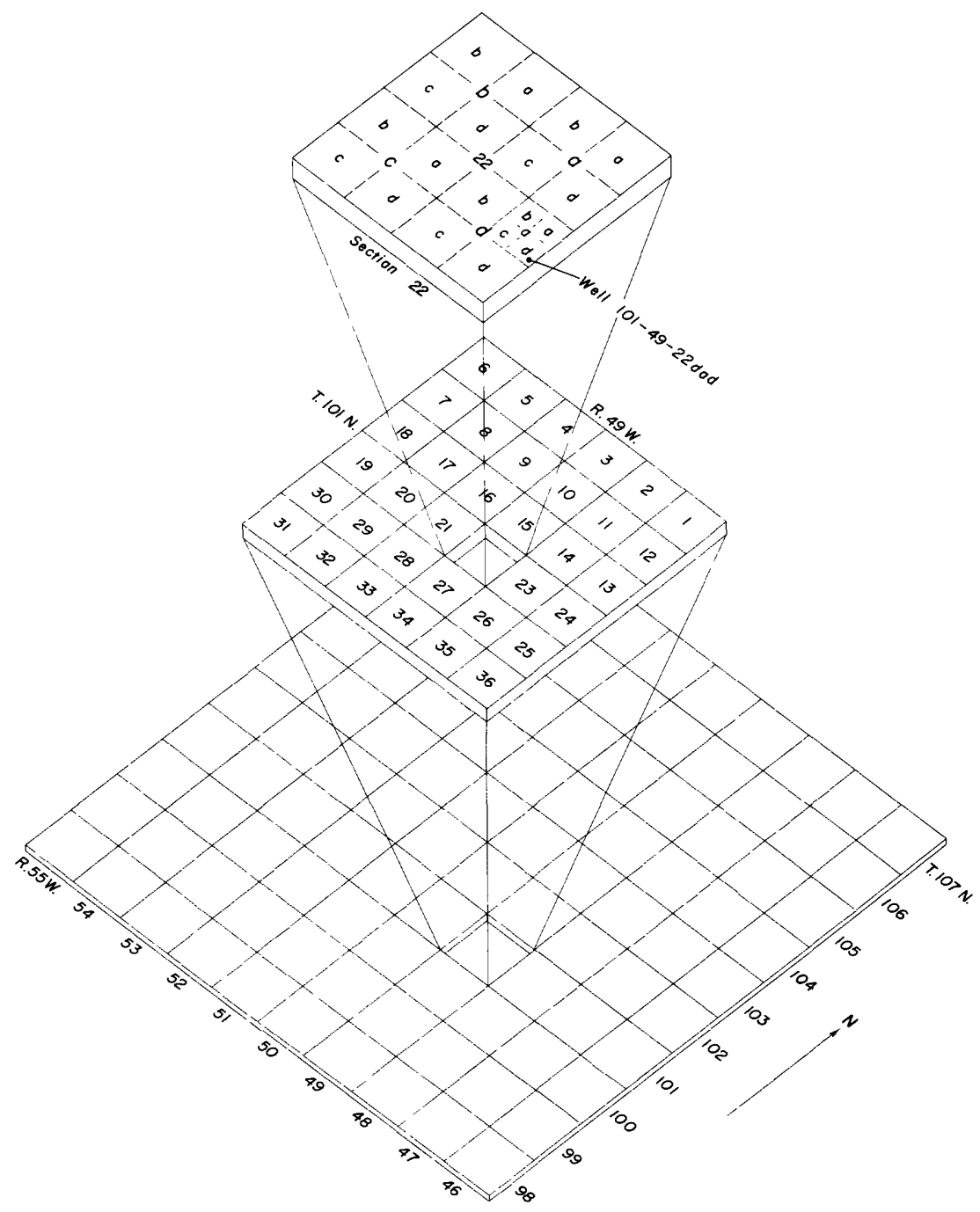

FIGURE 4.-Well-numbering system.

water in the ground may be transpired by the plants and returned to the atmosphere.

In the study area, little is evaporated from water surfaces because the area of surface water is small.

The amount of water returned to the atmosphere by transpiration in the Sioux Falls area is unknown; however, estimates were 
made of evapotranspiration losses from the aquifer. These losses include water exuded by plants and water evaporated from water surfaces and moist soils. The average annual precipitation is about 24 inches, but hydrographs of water-level fluctuations in selected observation wells indicate that nearly all of the approximately 12 inches that percolates through the soil to the aquifer is later removed from the aquifer by evapotranspiration.

Hydrographs of water levels in observation wells in the well field show long-term water-level declines that are intermittently interrupted by recharge resulting from floods. After the rising trends imposed by the floods are no longer evident, the trend of declining water levels is reestablished.

\section{THE STREAM}

Water in the Big Sioux River (including the diversion channel) is the most important surface-water resource in the study area.

\section{CHARACTER OF THE STREAM}

The Big Sioux River at the stream-gaging station near Dell Rapids drains an area of more than 5,000 square miles; however, about 2,000 square miles of the drainage area is usually noncontributing. The river originates in northeastern South Dakota and drains glacial till and outwash plains as it runs southward to its junction with the Missouri River at Sioux City, Iowa. The stream has a low and nearly uniform slope except where it flows over outcrops of resistant Sioux Quartzite near Dell Rapids and Sioux Falls. (See Frontispiece.) In the study area the stream has both oxbow meanders, which have a radius of curvature of about 750 feet, and straight reaches as long as 2 miles. The streambed material consists of permeable silt and sand except in the backwater area behind the diversion dam and the weir; there it consists predominantly of relatively impermeable clay and silt but interspersed in it are small amounts of permeable sand.

\section{OCCURRENCE OF FLOW}

The average annual discharge at the gaging station near Dell Rapids for the period 1949-68 was 246 cfs (cubic feet per second). The 2-year period of February 1958 through January 1960 is the period when the most severe low-flow conditions were recorded. Monthly mean discharges for this period at the station near Dell Rapids are given in table 2.

Flow-duration curve.-The flow-duration curve is a cumulativefrequency curve that shows the percentage of time that specified 
TABLE 2.-Monthly mean discharge of Big Sioux River near Dell Rapids, February 1958-January 1960

\begin{tabular}{|c|c|c|c|}
\hline \multirow[b]{2}{*}{ Month } & \multicolumn{3}{|c|}{ Discharge, in cubic feet per second } \\
\hline & 1958 & 1959 & 1960 \\
\hline January _------ & & 2.5 & 7.38 \\
\hline February ------ & 25.2 & 1.79 & -- \\
\hline March _.......- & 96.6 & 113 & --- \\
\hline April & 209 & 45.3 & -- \\
\hline May & 136 & 51.4 & -- \\
\hline June - & 90.9 & 27.4 & --- \\
\hline July & 35.1 & 6.22 & - \\
\hline August & 11.5 & 3.88 & -- \\
\hline September & 4.80 & 2.50 &.- \\
\hline October - & 4.57 & 2.21 & --- \\
\hline November & 9.70 & 6.2 & -- \\
\hline December & 6.3 & 9.7 & --- \\
\hline
\end{tabular}

discharges are equaled or exceeded. Flow-duration curves are useful for many purposes. To the extent that the curve is representative of long-term conditions, it may be used to predict availability and variability of future flows.

Drainage-basin characteristics are reflected in the shape of the flow-duration curve. The area under the curve is proportional to the mean discharge. The slope of the duration curve is an index of storage within the basin. The moderately steep slope of the flow-duration curve (fig. 5) for the gaging station near Dell Rapids indicates considerable storage within the basin. The change in slope at the low end of the curve indicates the effect of ground water released from storage on low streamflows.

The duration curves show that the average discharge rate of $246 \mathrm{cfs}$ is equaled or exceeded only 20 percent of the time.

One-third-month flow-probability curves.-During dry weather, which is typical for late summer, fall, and winter, daily discharges are low. Therefore, it is useful to know the percent probabilities that various discharges will be equaled or exceeded. Rakness (1970), using an average of the daily flow for one-third-month intervals, prepared flow curves for various percent probabilities as shown in figure 6 .

The data used were collected at gaging stations at Sioux Falls and near Dell Rapids during 1948-68.

Low-flow frequency curve.-A low-flow frequency curve is a graph showing the magnitude and frequency of minimum flows for a consecutive period of time. Figure 7 shows the recurrence interval and flow at the gaging station near Dell Rapids for the 


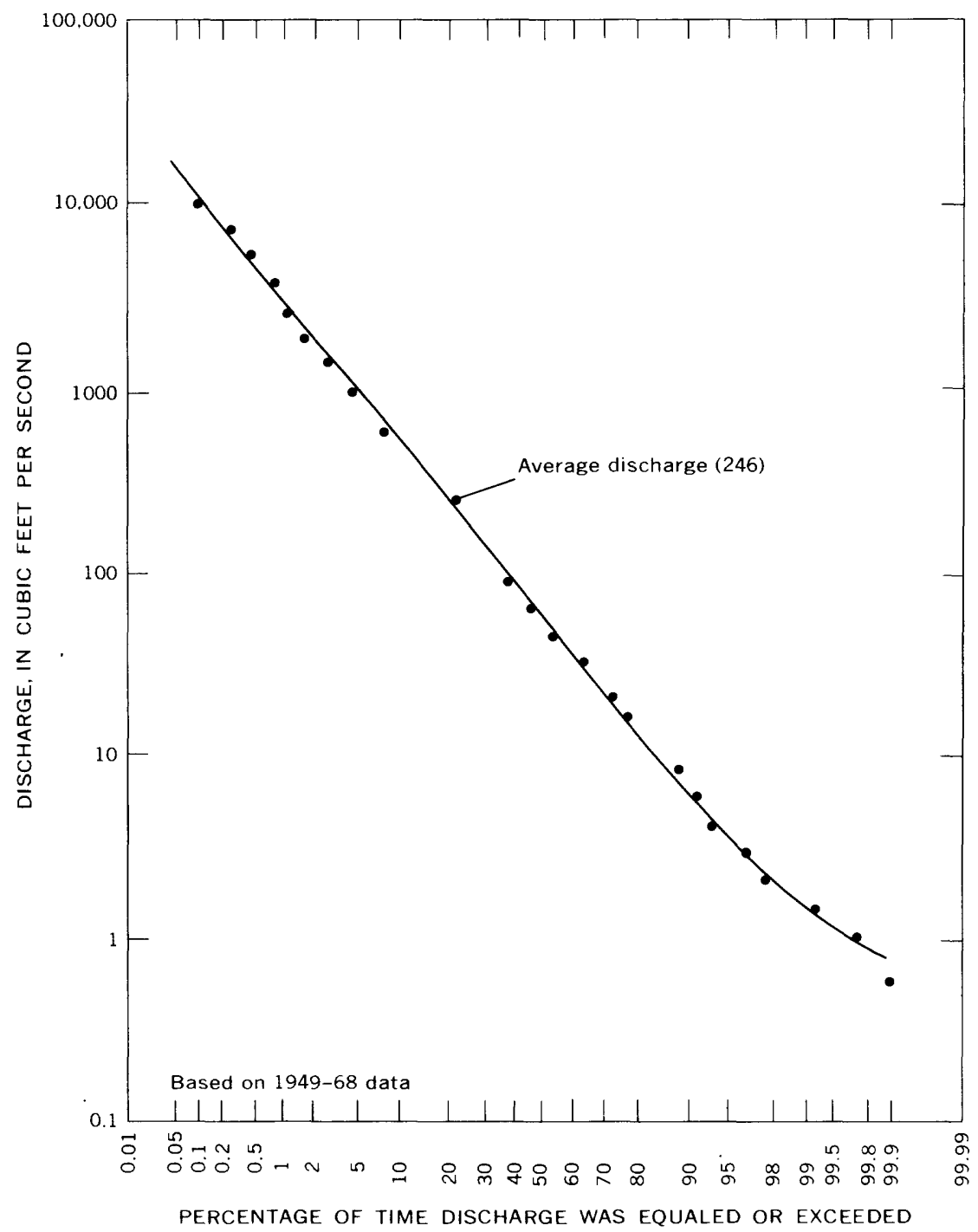

FIgURE 5.-Flow-duration curve of daily discharges of the Big Sioux River near Dell Rapids.

commonly used low-flow duration periods of $1,3,7,14,30,60,90$, 120,183 , and 365 days.

Flood-frequency curve.-A flood-frequency curve is a graph showing the recurrence intervals, plotted as abscissa, at which floods of the magnitude indicated by the ordinate are equaled or exceeded. At the gaging station near Dell Rapids, flood discharges 


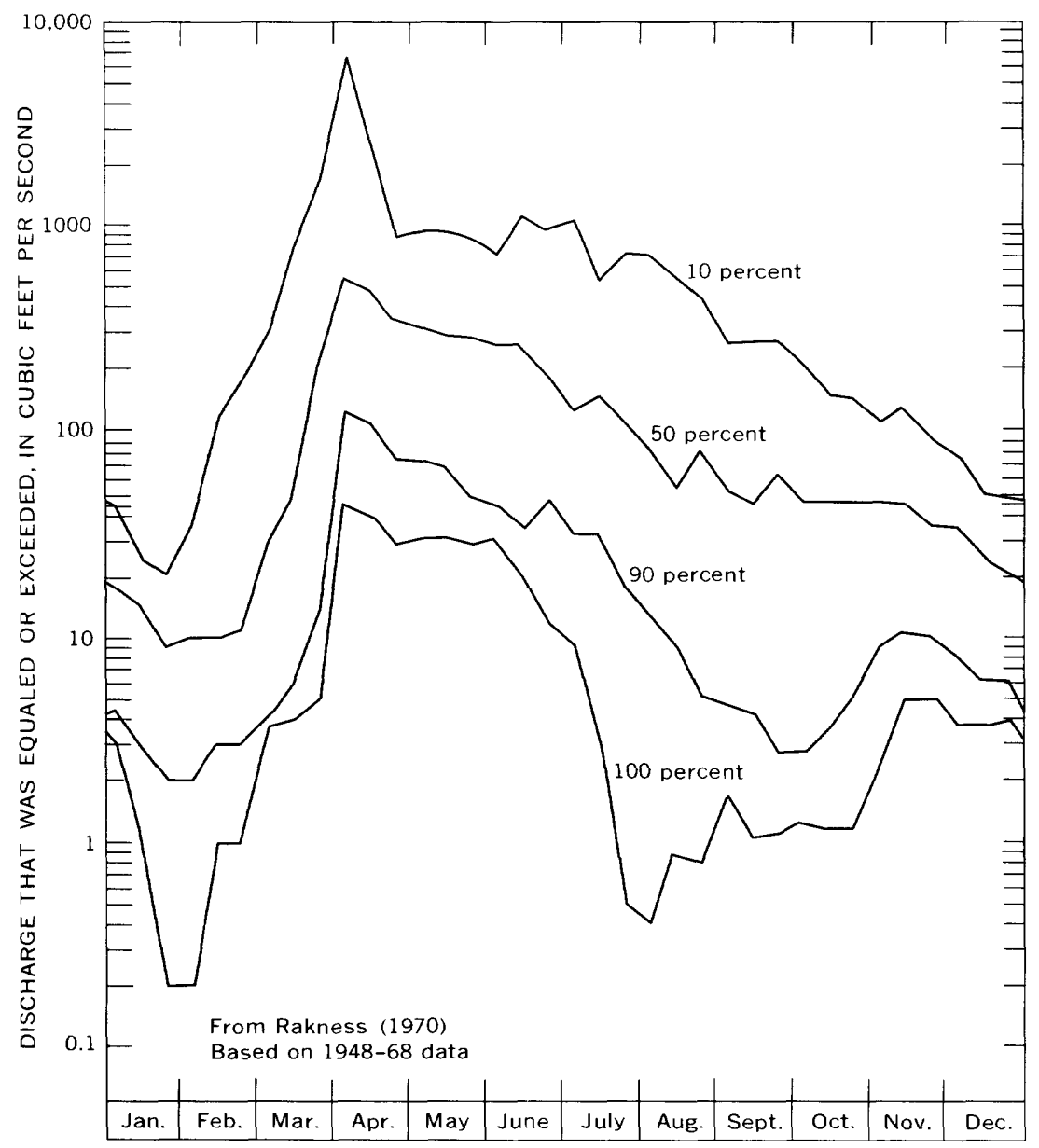

FIGURE 6.-Probability of flow for indicated intervals during the year in the Big Sioux River near Dell Rapids.

that exceed bankful stage have a recurrence interval of about 2.3 years. (See fig. 8.)

\section{THE AQUIFER}

A glacial outwash deposit consisting of sand, sand and gravel, and some boulders forms the large aquifer extending from near Dell Rapids to Sioux Falls. The aquifer underlies alluvial floodplain deposits along the Big Sioux River and has an area of about 33 square miles. (See pl. 1A.) It is confined both on the north and on the south by the nearly impermeable Sioux Quartzite.

A ridge underlain by Sioux Quartzite extends southwestward 
from the northeast corner of sec. 9, T. 101 N., R. 49 W., and is referred to as the southeast boundary in this report. It is composed of relatively impermeable glacial till with thin permeable sand lenses. The more than 80 feet of head difference between the water table north of the ridge and the level of water in the river south of the ridge causes some water to move out of the aquifer through the thin permeable sand lenses.

Low hills composed of till and loess define the edge of the Big Sioux River flood plain and constitute nearly impermeable boundaries for most of the aquifer. However, at certain locations the aquifer extends beneath the till hills, such as in the southwest and

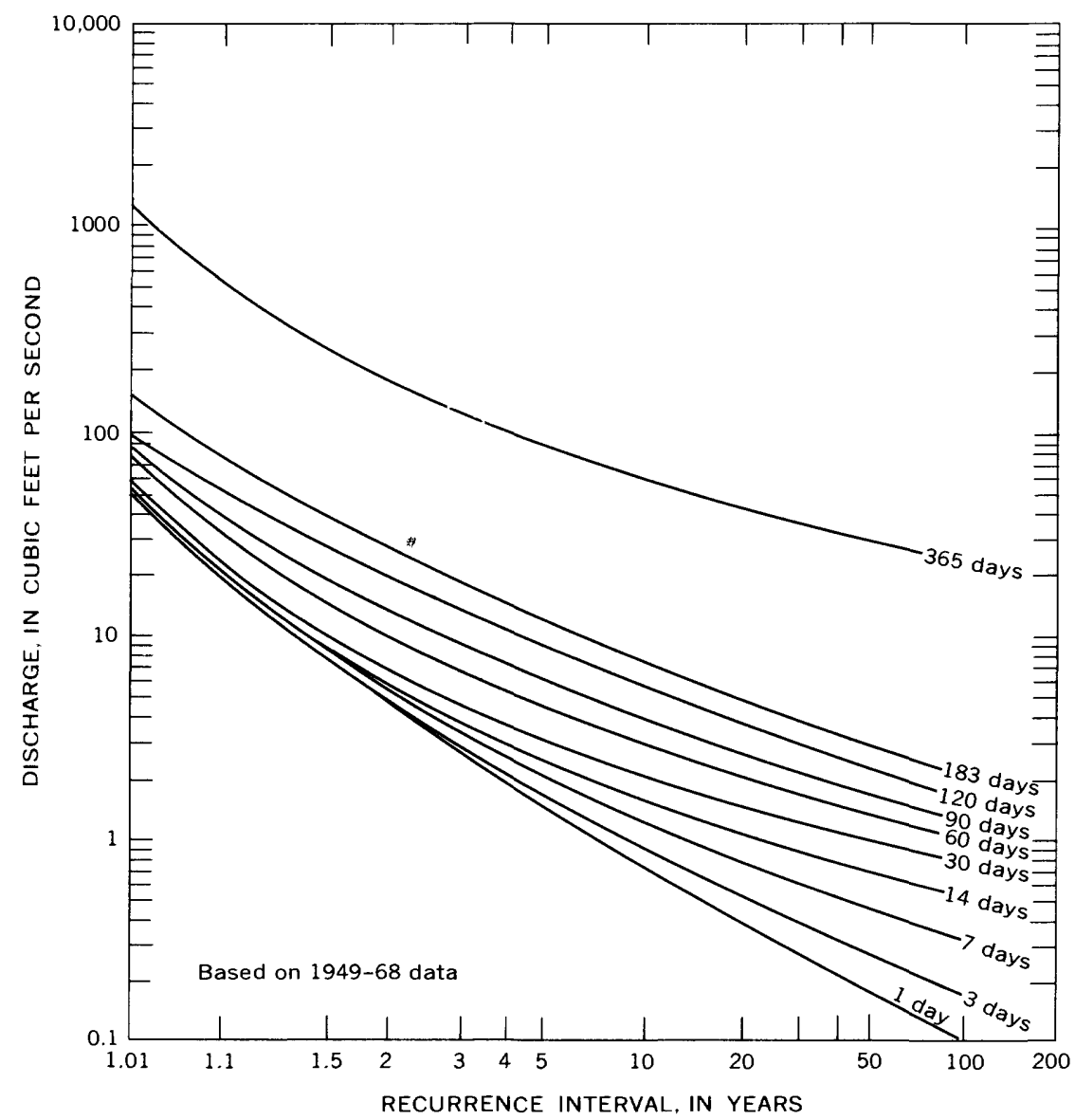

FiguRE 7.-Magnitude and frequency of minimum average consecutive-day discharges of the Big Sioux River near Dell Rapids. 


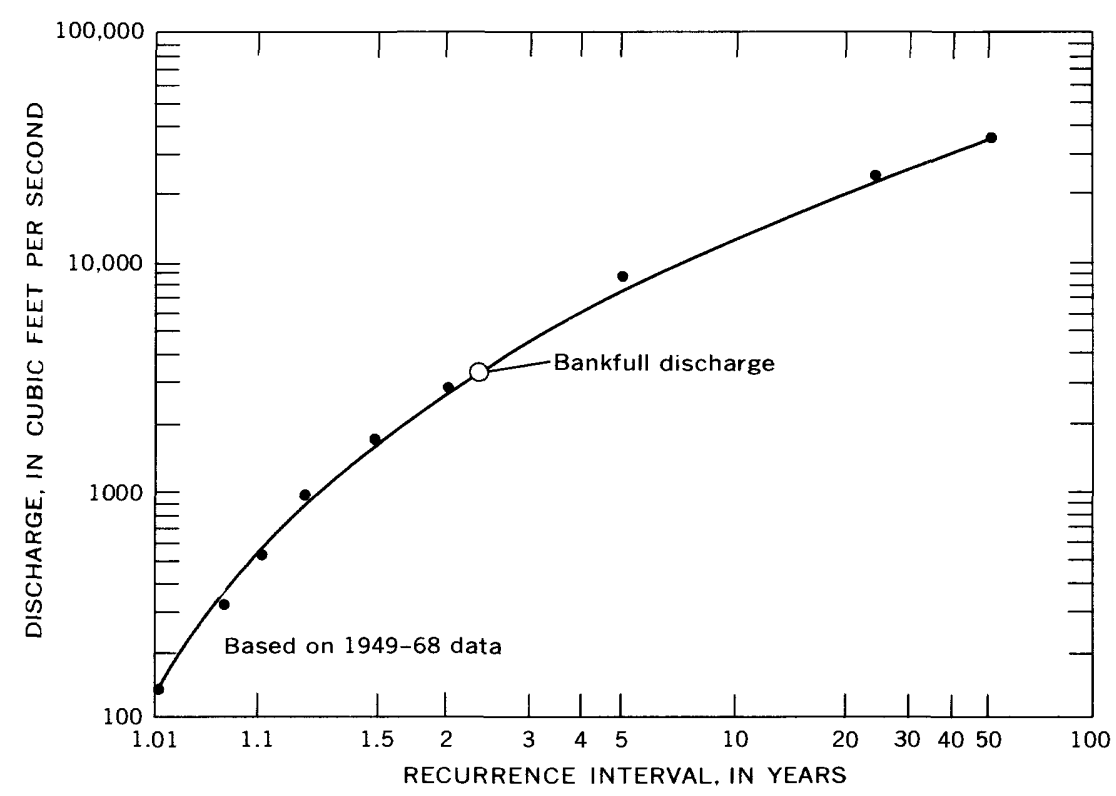

FIGURE 8.-Peak discharges of the Big Sioux River near Dell Rapids.

the southeast corners of the area, as shown by the dashed lines in plate $1 A$.

Although the aquifer is probably contiguous with the Skunk Creek outwash in sec 11, T. 101 N., R. 50 W., and although a narrow and shallow aquifer outlet exist in sec. 8, T. 101 N., R. $49 \mathrm{~W}$., the flatness of the water table in both of these areas indicates little water movement.

\section{THICKNESS}

Commonly the aquifer thickness ranges from 20 to 50 feet. In general, it is thickest at the Sioux Falls airport and thins northward. The thickness of the aquifer below the water table is called the saturated thickness and is a very important factor in the design of wells. Plate $1 A$ shows the saturated thickness and the hydrologic boundaries of the aquifer. Wells that yield water with a minimum amount of drawdown are essential because the saturated thickness is commonly 30 feet or less.

\section{HYDRAULIC CONDUCTIVITY AND TRANSMISSIVITY}

Hydraulic conductivity $(K)$ and transmissivity $(T)$ are both measures of the ease with which water will move through an 
aquifer. The relation in a horizontal direction between the two parameters is

$$
T=m K
$$

where $m=$ aquifer thickness.

Samples of the aquifer were studied by Rothrock and Otton (1947), Ellis, Adolphson, and West (1969), and others to determine hydraulic conductivity or transmissivity. Aquifer tests by Rothrock and Otton (1947), Ellis, Adolphson, and West (1969), the Ranney Water Systems, Inc. (1956a, 1956b, 1957, 1961) and others have also been made to determine the hydraulic conductivity and transmissivity.

Transmissivity of the aquifer ranges from zero at the edges to more than 100,000 gpd per ft (gallons per day per foot) at the well field. (One gallon per day equals 0.134 cubic foot per day.) Plate $1 A$ shows the variation of transmissivity within the aquifer.

\section{SURFACE-WATER AND GROUND-WATER RELATIONSHIP}

Water moves easily between the aquifer and the stream. During dry periods the base flow of the Big Sioux River is primarily water released from ground-water storage from the aquifer described in this report and from a similar aquifer beneath the flood plain of the river north of Dell Rapids. During periods of high streamflow, water from the river recharges the aquifer through the streambanks; during floods, large amounts of water on the flood plain percolate through the overlying topsoil and alluvium and recharge the aquifer. Most of the water pumped from the city well fields is water derived from the Big Sioux River. For example, calculations of water balance for 1968 indicate that less than $1 \mathrm{mgd}$ was transmitted into the well field by underflow through the aquifer. Very little water was transmitted by underflow out of the well field at the southern aquifer boundaries. Records of water-level changes during the year indicate that the change in ground-water storage was small. Examination of pumping records of individual wells for 1968 shows that the wells near the river produced about nine-tenths of the water pumped during the year. Therefore, about nine-tenths of the $10 \mathrm{mgd}$ pumped by the city of Sioux Falls during 1968 came initially from the river. For this reason, development of ground water in the aquifer depends on the amount of surface water in the Big Sioux River.

The water is lost from the river to the aquifer by infiltration through the streambed. The rate of streambed infiltration is a function of the thickness and hydraulic conductivity of the streambed material, the viscosity of the water, and the difference in 
head through the streambed. The rate of streambed infiltration can be increased by damming the river and thereby increasing the head. However, the dams may form sediment traps and ultimately reduce the hydraulic conductivity of the streambed materials.

\section{SEEPAGE MEASUREMENTS}

To aid in the analysis of the aquifer-stream relationship, discharge measurements were made nearly simultaneously at carefully selected stream locations above and below points of inflow and outflow to determine stream gain or loss. Interpretations of stream gains and losses from these measurements must be made with a knowledge of the inherent errors in the method of measurement. Each individual measurement is subject to a maximum error of about 5 percent. A group of such measurements is called a seepage run.

Several seepage runs were made at various times of the year and at various rates of flow to define the water movement between the aquifer and the river. Locations of the measuring sites are shown in figure 9. Results of the seepage runs are given in table 3. All the runs indicate that water is moving from the stream to the aquifer in the vicinity of the well field. This fact supports other data in showing that most of the water pumped from the well field is from the river. The seepage runs also show that the stream gains water between Dell Rapids and Renner.

The following formula was used to determine the streambed infiltration rate $(p)$ for those reaches where the water table was below the streambed:

where

$$
p=\frac{\Delta Q_{s}}{w l}
$$

$\Delta Q_{\dot{c}}=$ change of streamflow between measuring points;

$l=$ length of stream between measuring points;

$w=$ average width of streambed.

The streambed infiltration rate for the part of the Big Sioux River adjacent to the airport and the well field was computed to be about 6 gpd per sq ft (gallons per day per square foot).

\section{AQUIFER PUMPING TESTS}

Results of aquifer tests from pumped wells near the stream were used to calculate streambed infiltration. The aquifer tests were analyzed by using type curves for a single boundary (Stall- 


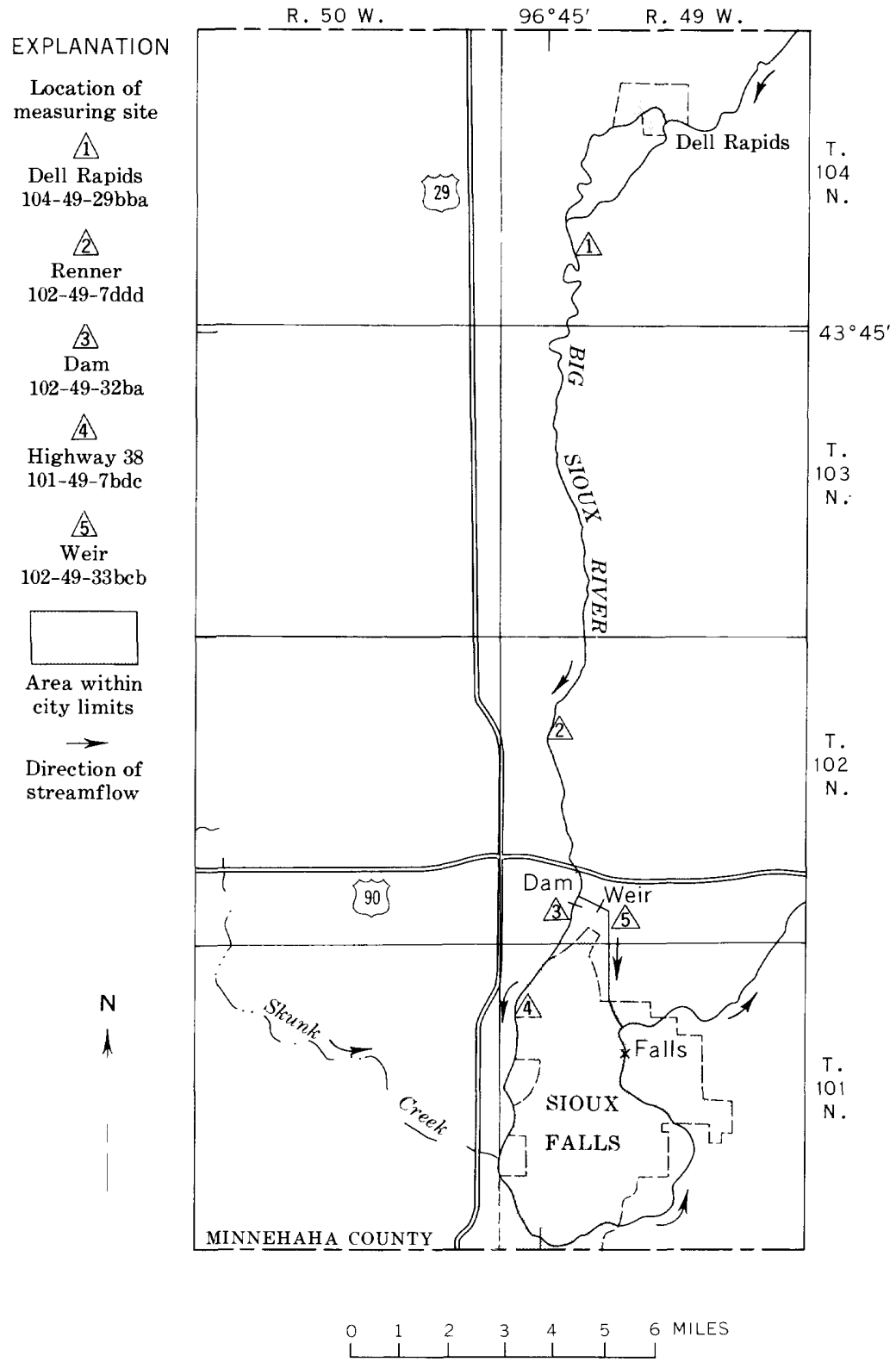

FIgURE 9.-Locations of discharge-measurement sites used to determine loss or gain of water in the in the Big Sioux River.

man, 1963, p. 45-47). This method of analysis is used to determine the distance of the line source (stream) from the pumped well. 
TABLE 3.-Discharges of the Big Sioux River used to determine loss or gain of streamflow

[Locations of measurement sites are shown in figure 9]

\begin{tabular}{rrrccc}
\hline & \multicolumn{5}{c}{ Measurements of discharge (cfs) } \\
\cline { 2 - 6 } Date & $\begin{array}{c}\text { Dell } \\
\text { Rapids }\end{array}$ & Renner & Dam & Weir & Highway \\
\hline $11-6-64$ & 19 & 22 & 0.68 & 16 & -16 \\
$2-23-67$ & 10 & 11 & 6.5 & 1.3 & 0.57 \\
$4-25-67$ & 175 & 184 & 177 & 1.3 & 165 \\
$11-14-69$ & 73 & 83 & 5.9 & 57 & .13 \\
\hline
\end{tabular}

1 Estimated.

The percentage of the pumped water that is intercepted from the stream at any given time can be determined by using a procedure outlined by Theis $(1941, \mathrm{p} .735)$ and assuming that initially there is no flow between the aquifer and the reach of the river being studied.

It can be shown mathematically from Theis' equation that an amount equal to a little more than half the quantity derived from the stream originates opposite the pumped well between points on the recharge boundary whose distance apart is equal to twice the distance $(a)$ between the line source and the pumped well (Norris and Fidler, 1969, p. 41). Noting that loss of flow in the stream is equal to the decimal percentage $(P)$ of the flow being diverted, an estimate of the streambed infiltration rate can be made from

$$
p=\frac{P Q}{4 w a}
$$

where $Q=$ pumping rate. The rates of streambed infiltration determined from the three aquifer tests were 7.4, 4, and $6.2 \mathrm{gpd}$ per sq ft.

Ranney Water Systems, Inc. made an aquifer test in August 1961 using a pumping well located north of the diversion channel about midway between Silver Creek and the Big Sioux River. This test indicated a hydraulic conductivity of the channel deposits in the diversion channel of $3.2 \mathrm{gpd}$ per sq $\mathrm{ft}$ at $26^{\circ}$ Celsius (centigrade). It should be noted that by 1961 sediment had been deposited in the diversion channel for more than a year and that the value for hydraulic conductivity is only representative of the diversion channel deposits behind the weir and possibly of the Big Sioux River sediments upstream from the dam for about a half mile. 
The values of streambed infiltration appear reasonable in comparison with infiltration rates in other streambeds. (See Walton and Ackroyd, 1966, p. 3-20.) Figure 2 shows the location of aquifer tests used to determine infiltration rates.

Streambed infiltration rates vary with changes of temperature or viscosity of the water. Water temperatures of the Big Sioux River measured at the Dell Rapids stream-gaging station ranged from $0^{\circ} \mathrm{C}$ to $29^{\circ} \mathrm{C}$ in 1968 - a viscosity range of 1.80 to about 0.82 centipoise. Thus, streambed infiltration rates varied seasonally by a 2.2 to 1 ratio.

\section{SAMPLING OF THE DIVERSION CHANNEL}

The weir on the diversion channel and the dam on the Big Sioux River have formed stream-sediment traps. A large volume of sediment has been deposited in the backwater behind the weir, in the backwater behind the dam, and in Silver Creek north to State Highway 38A. This sediment, in general, is only moderately permeable and restricts surface-water recharge to the aquifer. To determine the extent of sedimentation and the hydraulic conductivity of the sediments, the streambed was sampled in the diversion channel between the weir and the Big Sioux River, in the Big Sioux River between the dam and the north line of sec 32, T. 102 N., R. 49 W., and in Silver Creek from the diversion channel to State Highway 38A. Sampling was done in the winter through the ice. Holes were augered and cored through the sediment and into the original streambed; representative samples were collected along cross sections surveyed as shown in figure 10 . Vertical hydraulic conductivity of the sample was determined by the U.S. Geological Survey Hydrologic Laboratory in Denver, Colo. Figure 11 shows a cross-sectional view of the sediments at a typical location in the diversion channel between the weir and the dam.

The effective vertical hydraulic conductivity $\left(K_{s}\right)$ of the trapped sediments was calculated from

$$
K_{s}=\frac{M}{\frac{m_{1}}{K_{1}}+\frac{m_{2}}{K_{2}}+\frac{m_{3}}{K_{3}}+* * * \frac{m_{n}}{K_{n}}},
$$

where

$m_{1}, m_{2}, m_{3} * * * m_{n}=$ the thickness of each layer;

$K_{1}, K_{2}, K_{:} * * * K_{n}=$ the vertical hydraulic conductivities of each layer; 


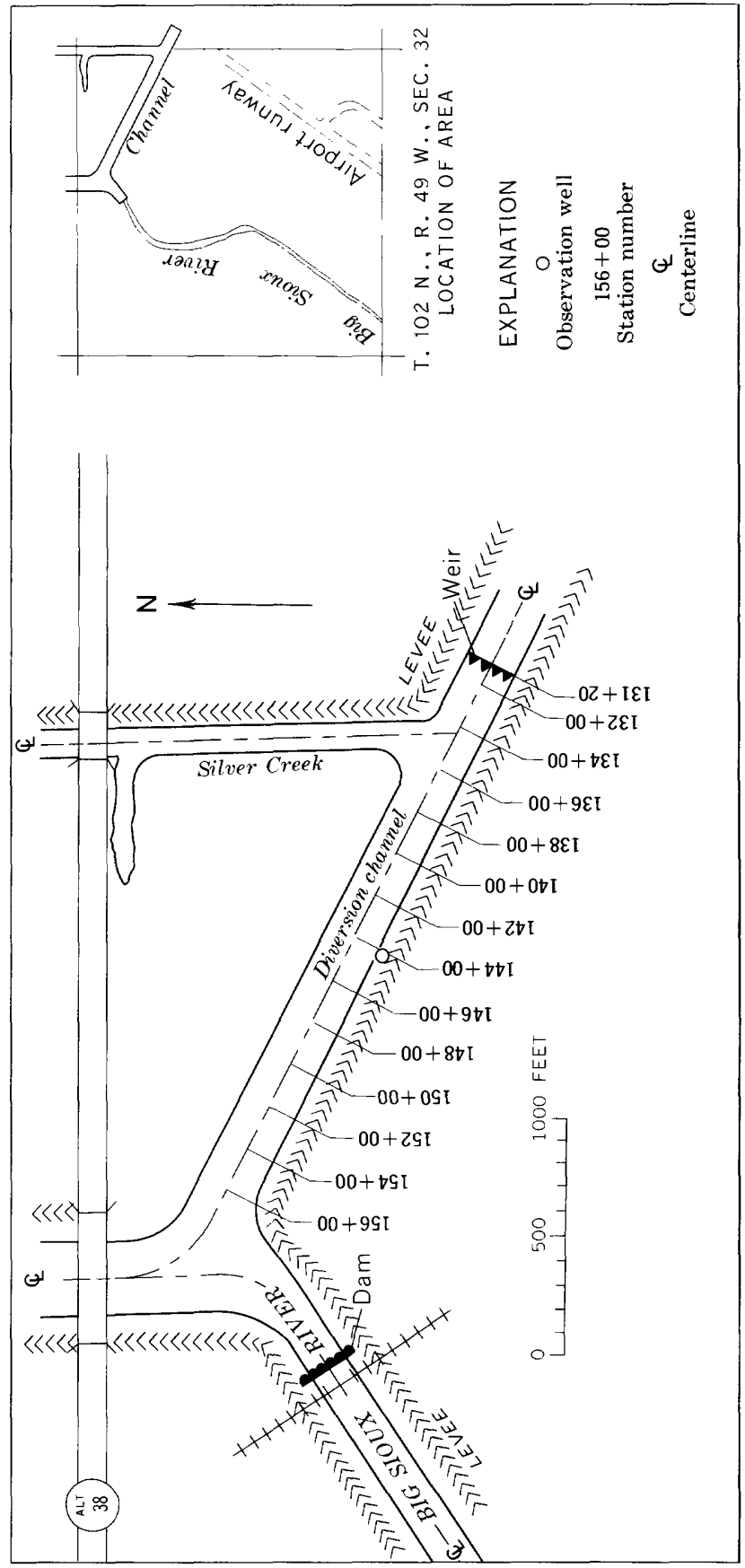

वే 







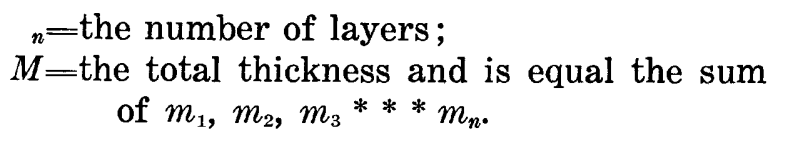

The vertical hydraulic conductivity of the diversion channel streambed is about $0.1 \mathrm{gpd}$ per sq $\mathrm{ft}$, and the sediment thickness is about 2.8 feet. The fixed-elevation weir holds the water level at a nearly constant elevation of about $71 / 2$ feet above the bottom. Thus, the infiltration rate per unit area, when the water table of the aquifer is at the base of the trapped sediments, is about 0.3 gpd per sq $\mathrm{ft}$ as calculated by

$$
p=\frac{K_{s} \Delta h}{M},
$$

where $\Delta h=$ head differential across the sediments.

\section{ELECTRIC LOGGING THE DIVERSION CHANNEL}

A continuous record of the types of sediment in the diversion channel behind the weir was obtained by an electric logging survey of the section. A single-point-resistivity and spontaneouspotential probe was dragged on the bottom along the centerline of the diversion channel. The electric log was compared with samples of bed material taken from along the centerline, and the trace of the $\log$ was used to differentiate between the various types of sediment. The electric log was useful in locating permeable sands in the streambed and in showing that silts and clays were the predominant sediment types. Part of the channel was also logged with a detector probe for gamma radiation. An interpretation of lithology from the gamma-ray intensity record was also used to differentiate types of sediment.

\section{DREDGING THE DIVERSION CHANNEL}

The infiltration rate of water through the streambed sediments deposited behind the weir and the dam would be greatly increased if the sediment, which has relatively low hydraulic conductivity, were removed.

A pilot project of sediment removal was made during October 1967. A continuous-water-level recorder was installed in an observation well constructed at station $144+00(102-49-32 \mathrm{adac})$ on the south bank of the diversion channel. A dredge was used to remove the sediment near the centerline of the channel, which is about 100 feet from the observation well. The water level in the 
observation well is shown in figure 12. The water level in the diversion channel was constant. The rise in water level in the observation well indicates that the dredging of the sediment from the area to expose the aquifer resulted in an increased rate of infiltration.

\section{THE ANALOG MODEL}

\section{ELECTRIC ANALOG MODELING}

The unsteady confined flow of water in a uniform porous medium is defined by the partial differential equation (Jacob, 1950, p. 333)

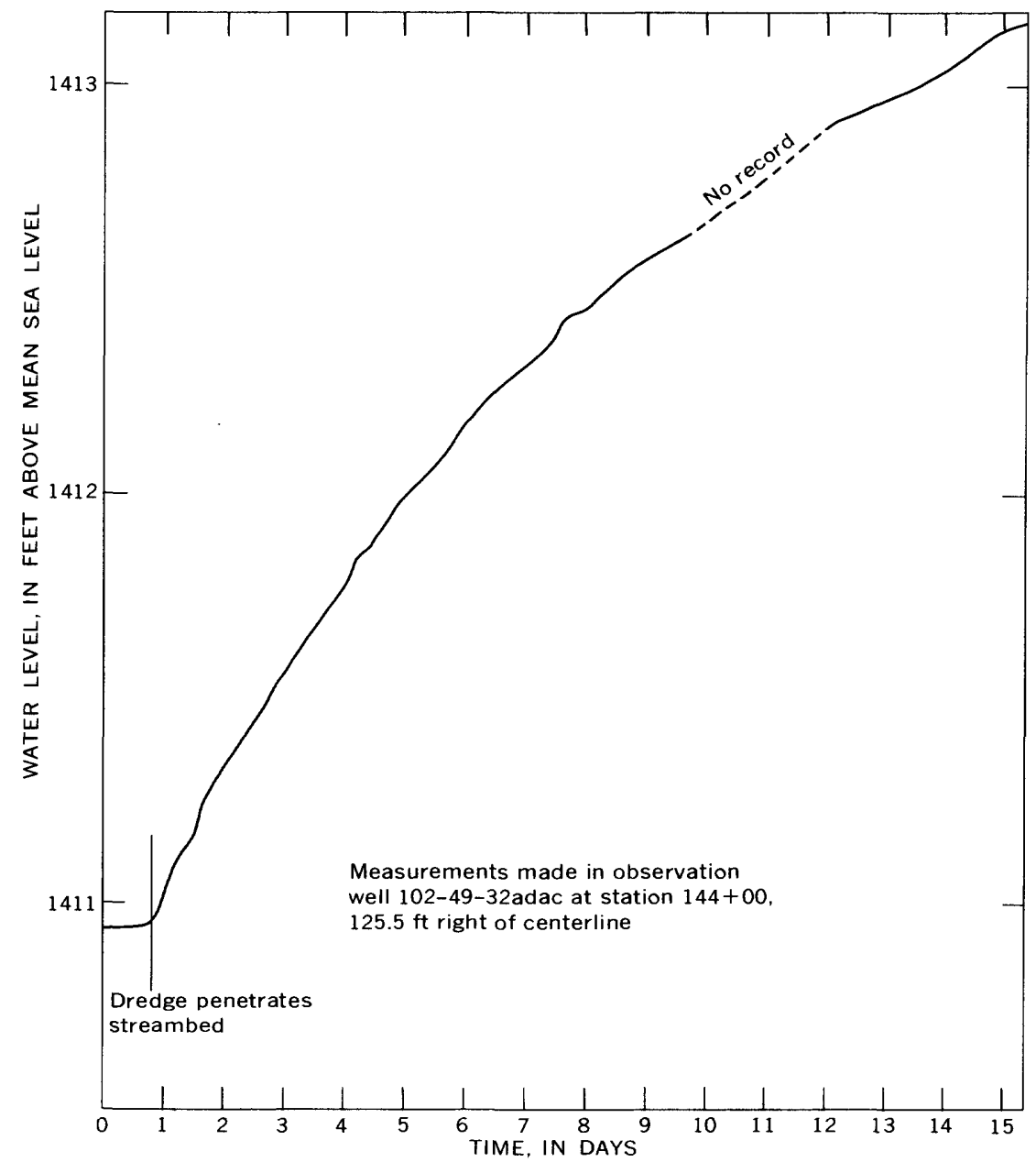

FIgURE 12.-Water-level rise resulting from dredging of sediment from the diversion channel. 


$$
\frac{\partial^{2} h}{\partial x^{2}}+\frac{\partial^{2} h}{\partial y^{2}}=\left(\frac{S}{T}\right)\left(\frac{\partial h}{\partial t}\right)
$$

where

$h=$ head at any point whose coordinates are $x, y$, and $t=$ time.

The similar equation for a two dimensional diffiusion field in electricity (Karplus, 1958, p. 33) is

$$
\frac{\partial^{2} V}{\partial x^{2}}+\frac{\partial^{2} V}{\partial y^{2}}=R C \frac{\partial V}{\partial t}
$$

where

$V=$ voltage,

$R=$ resistance, and

$C=$ capacitance.

The identical form of the equations indicates that the flow of electricity is analogous to the flow of water in a porous medium under artesian conditions. Voltage is analogous to head, resistance is analogous to the reciprocal of transmissivity, and capacitance is analogous to storage coefficient. A detailed description of the theory of electrical analog modeling is given by Patten $(1965, \mathrm{p}$. 41-50).

An analog-model solution of an unconfined aquifer problem is not presently practical. However, analog-model solutions of artesian conditions can be adjusted to approximate water-table conditions if a correction (Jacob, 1944) is applied. This correction is

$$
s_{w}=m\left(1-\sqrt{1-\frac{2 s_{a}}{m}}\right) \text {, }
$$

where

$s_{w}=$ drawdown, corrected for dewatering of unconfined system;

$s_{a}=$ drawdown, predicted by model of confined system;

$m=$ original saturated thickness.

The correction shown in this equation was applied to all results from analog-model studies.

\section{DESCRIPTION OF MODEL}

The analog model is made of regular arrays of resistors, capacitors, and current-limiting diodes mounted on a masonite peg board as shown in figure 13. 
The aquifer is continuous, whereas the analog model is discontinuous, being composed of a two-dimensional resistor-capacitor network as shown in figure $14 \mathrm{~A}$. Each junction, called a node, consists of four resistors and a capacitor as shown in figure $14 B$. If the area of the squares $\left(b^{2}\right)$ is made small it can be shown

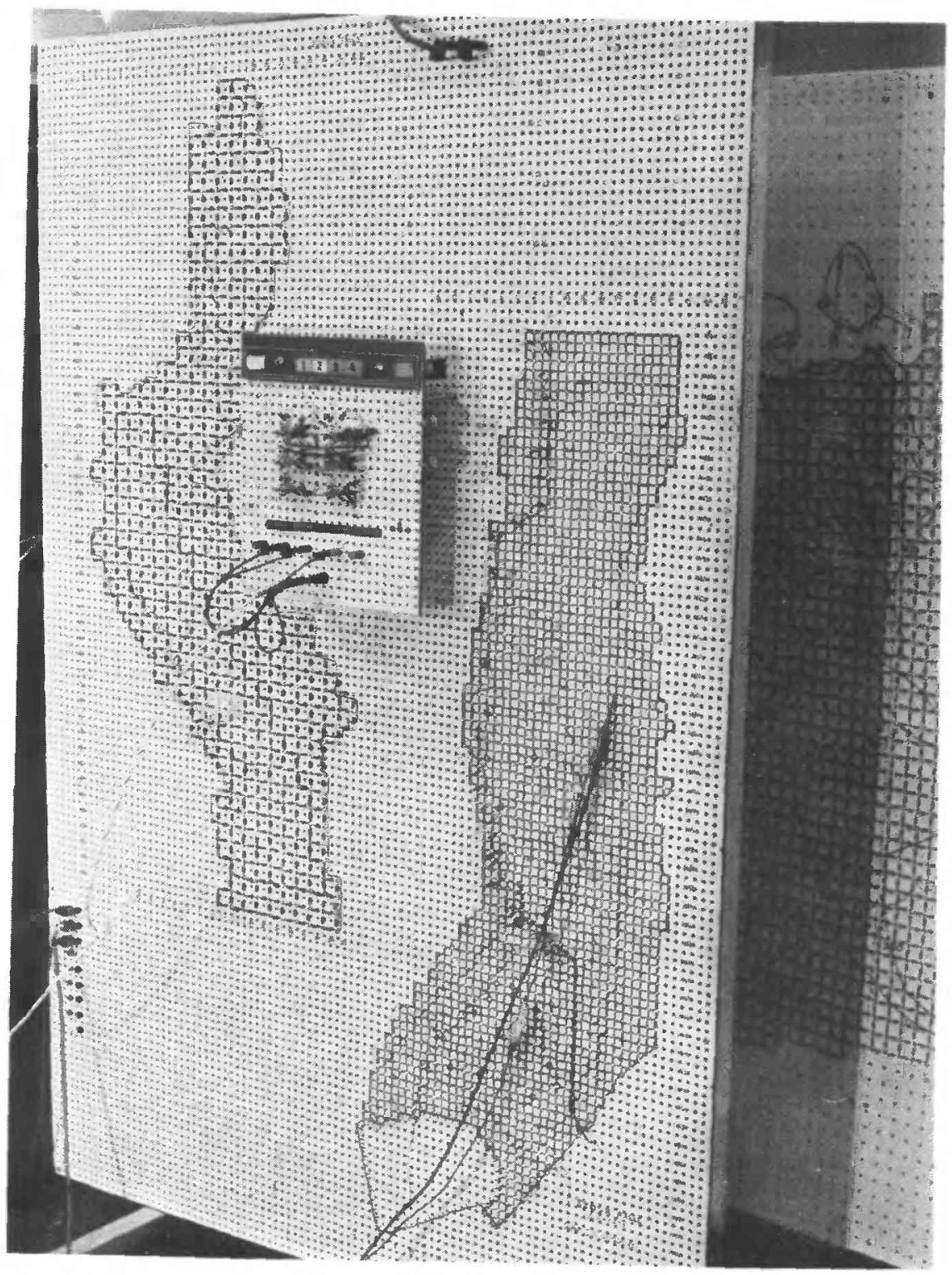

Frgure 13.-Analog model of the area studied. 
mathematically that the maximum error in modeling will approach zero as $b^{2}$ approaches zero.

The resistance value required to model transmissivity on an orthogonal network was determined by using the relation

$$
R=\frac{C_{2}}{C_{1} T}
$$

The value of capacitance needed to model storage was calculated using the equation

$$
C=7.48 \frac{C_{1}}{C_{2} C_{3}} b^{2} S,
$$

where $b=$ map distance, in feet, between nodes, and $C_{1}, C_{2}$, and $C_{3}$ are scale factors that relate flow of water to flow of electricity. Values for resistors and capacitors near the boundaries were calculated using vector-area and vector-boundary techniques described by Karplus (1958).

The finite-difference form of the partial-differential equation for nonsteady state, two-dimensional flow in a homogeneous, isotropic, and infinite artesian aquifer as given by Stallman (1956) is

$$
T\left(h_{2}+h_{3}+h_{4}+h_{5}-4 h_{1}\right)=b^{2} S \frac{\partial h}{\partial t}
$$

where $h_{1}, h_{2}, h_{3}, h_{1}$, and $h_{5}$ are heads at nodes arranged as shown in figure $14 A$.

The analogous equation for voltage at the vicinity of the node (fig. 14B) as given by Skibitzke (1961) is

$$
\frac{1}{R}\left(V_{2}+V_{3}+V_{4}+V_{5}-4 V_{1}\right)=C \frac{\partial V}{\partial t} \text {. }
$$

Each well was modeled by a resistor $R_{w}$ as shown in figure $14 C$. The value of the resistor is calculated by using the equation

$$
R_{w}=\frac{E C_{2}}{Q C_{1}}
$$

where $E$, the electrical potential applied to the well resistor, is much greater than $V i$ the voltage at nodes $1,2,3,4$, and 5 .

The streambed was modeled by attaching current-limiting diodes at the appropriate nodes. (See fig. 14C.) The current-limiting device is used to model rate of inflitration under a variable head up to a limiting rate. Once the continuity between the water surface in the stream and the water level in the aquifer is broken, 


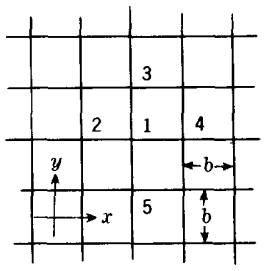

$\boldsymbol{A}$

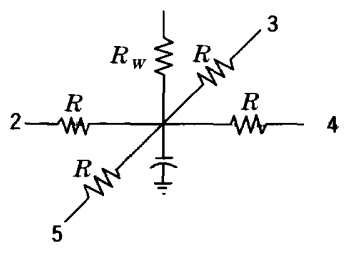

$B$

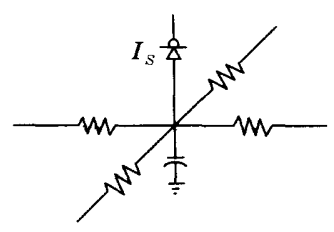

C

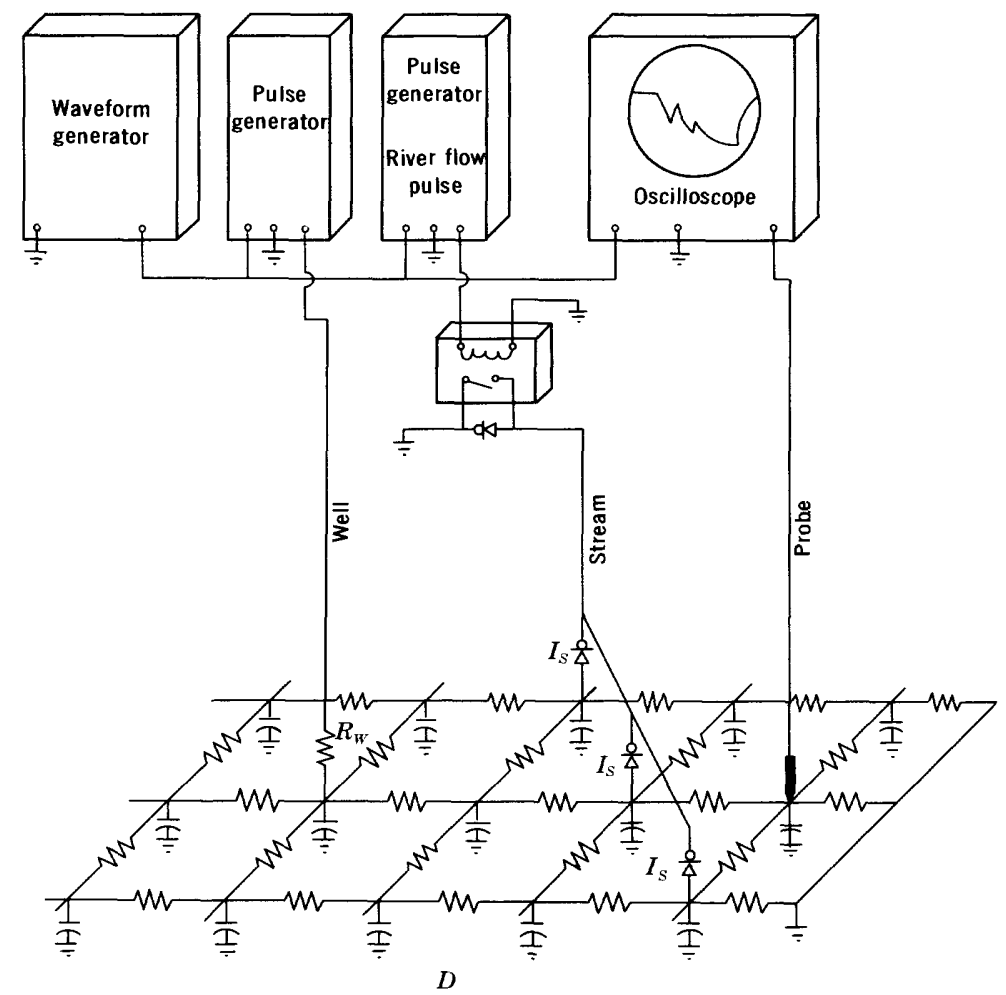

EXPLANATION

$\circ$ -

Switch, open
8

Current-limiting diode

FiguRE 14.-Finite-difference grid $(A)$; resistor-capacitor nets for modeling a pumping well $(\boldsymbol{B})$; resistor-capacitor net and currentlimiting diode for modeling a streambed $(C)$; and schematic diagram of analog model and operating components $(D)$. 
the rate of infiltration will become constant, so long as water flows in the river.

The maximum streambed-infiltration rate is a function of head in the streambed, the streambed area, the hydraulic conductivity of the streambed material, and the viscosity of the water. An average depth of 1 foot for the Big Sioux River sediments was selected to simplify the model. The streambed area was modeled as constant because the Big Sioux River generally has well-defined banks and a nearly uniform stream width. A nominal infiltration rate was selected to simplify the model.

The size of the current-limiting diode was calculated by

$$
I_{s}=\frac{p A}{C_{2}},
$$

where

$A=$ area of streambed modeled per node;

$p=$ infiltration rate, gallons per day per square foot; and

$I_{s}=$ maximum, or limiting, current through diode.

The streamflow was modeled by using a current-limiting diode switch as shown in figure $14 D$. This switch allows modeling of two different streamflow rates. The two-rate approximation simulated the actual streamflow conditions remarkably well.

\section{SOLUTION OF MODEL PROBLEMS}

The model was tested by simulating known hydrologic conditions and comparing the results with the measured results from the hydrologic system. If the comparison of the measured hydrologic conditions and the analog results showed poor agreement, the model was modified and tested again. This process of model verification was continued until the model accurately simulated the hydrologic system.

Many hydrologic problems were solved using the model. Four solutions of model problems are described in this report: storage depletion, $15 \mathrm{mgd}$ average daily pumping, $18 \mathrm{mgd}$ average daily pumping, and maximum average daily pumping rate.

\section{STOR:IGE DEPLETION}

PROBLFM

A study of the aquifer as the only element in the hydrologic system is useful in evaluating the relative importance of the aquifer as a water supply. To study the aquifer in this manner it is assumed that all pumped water is taken from storage within the 
aquifer (storage depletion). An analog-model solution was obtained using the modeling conditions listed below:

Pumping rate.-An approximation of the well-field pumping rate recorded for January 1965 through December 1968 was modeled as shown in figure 15.

Aquifer.-The aquifer was modeled with a transmissivity in three ranges as shown in plate $1 A$. The transmissivity zone of greater than $90,000 \mathrm{gpd}$ per $\mathrm{ft}$ was modeled as $92,000 \mathrm{gpd}$ per $\mathrm{ft}$, the zone of 15,000 to $90,000 \mathrm{gpd}$ per $\mathrm{ft}$ was modeled as $42,600 \mathrm{gpd}$ per $\mathrm{ft}$, and the zone of 0 to $15,000 \mathrm{gpd}$ per $\mathrm{ft}$ was modeled as $11,060 \mathrm{gpd}$ per $\mathrm{ft}$. A storage coefficient of 0.20 was used. Boundaries were modeled as impermeable.

Stream.-The stream was not modeled (no flow).

Streambed.-The streambed was not modeled.

Other.-Neither recharge from precipitation nor discharge by evapotranspiration was modeled.

\section{RESULTS AND CONCLUSIONS}

Figure 15 shows that all the water withdrawn from wells came from depletion of water stored in the aquifer. The area beneath the pumping curve and the zero ordinate is proportional to volume of water pumped. Correspondingly the area between the zero ordinate and the depletion of storage curve is also proportional to the volume of water pumped. The area between the zero ordinate and the pumping curve is equal to the area between the zero ordinate and the depletion of storage curve.

Plate $1 B$ shows the simulated decline of water levels at the end of a 1-year pumping period. The remaining saturated thickness at most wells in the well field was about 15-25 feet. It was assumed that each well was screened to the bottom of the aquifer and that the well would not perform adequately when the water level was lowered to within 10 feet of the bottom of the screen. Under these conditions, none of the wells failed until after 1 year's pumping; however, many wells failed after a little more than 1 year's pumping.

\section{FIFTEEN MILLION GALLONS PER DAY PUMPING}

PROBLEM

Because of the prediction of increased water demand by Sioux Falls in future years, an enlarged well field with an average daily pumping rate of $15 \mathrm{mgd}$ was tested under adverse hydrologic conditions. An analog-model solution was obtained by using the modeling conditions listed below: 
Pumping rate.-A daily average pumping rate of $15 \mathrm{mgd}$ was modeled. The January 1, 1969, well field was modeled with well locations as shown in figure 2 . It was assumed that the well field was producing at nearly maximum capacity at a daily average of $10.4 \mathrm{mgd}$ and with a maximum-day capacity of $27 \mathrm{mgd}$. The maximum-day capacity of the expanded well field was $21 / 4$ times the daily average pumping rate of $15 \mathrm{mgd}$ ( $34 \mathrm{mgd}$ ).

A number of hypothetical wells were modeled to meet both the increase of the daily-average demand and the maximum-day capacity. Eleven such wells, each with a maximum-day capacity of $0.75 \mathrm{mgd}$, were modeled. The locations of the additional wells are shown in plate $1 C$.

Past pumping records (U.S. Bureau Reclamation, 1969, p. 19) were examined to determine the distribution of pumping per month. Table 4 shows the monthly distribution of pumping and the approximation of this distribution which was used for modeling.

Aquifer.-The aquifer was modeled as in the previous problem, except that the southeast boundary was not modeled as a discharging boundary.

Stream.-The period (February 1958 through January 1960) having the most severe low-flow conditions recorded for the Big Sioux River near Dell Rapids was selected for modeling. (See table 2.) Streamflow was modeled at two rates; a high rate in excess of the maximum streambed infiltration rate and a low rate simulating low-flow conditions averaging $5.65 \mathrm{cfs}$.

Streambed.-The streambed infiltration rate was modeled at 6

TABLE 4.-Water use by month for the city of Sioux Falls

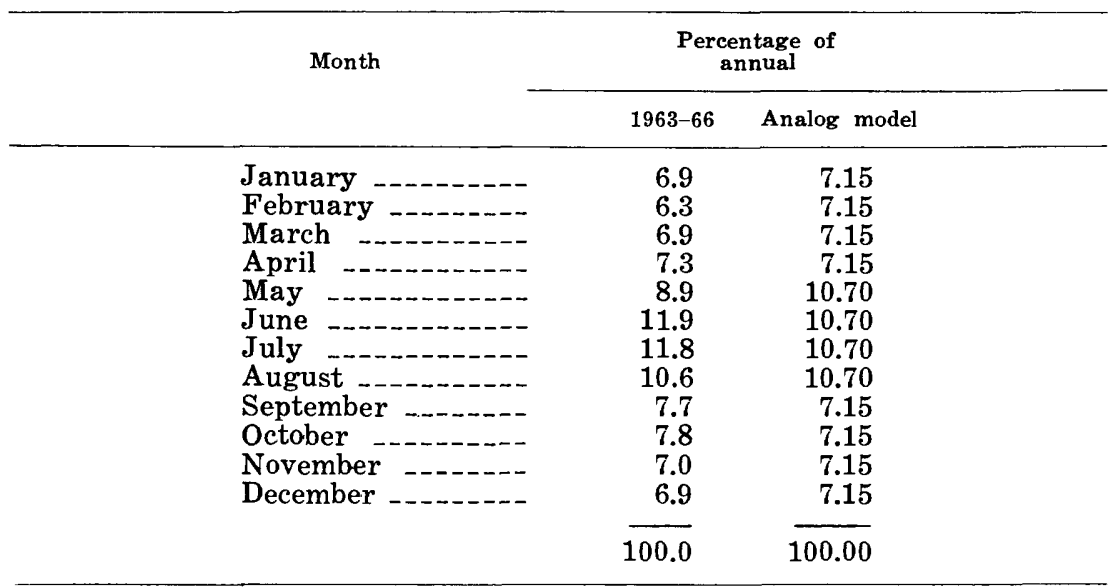


gpd per sq ft, except for the portion of the streambed in the backwaters behind the weir in the diversion channel and behind the dam on the river. This part of the streambed was modeled at 1 gpd per sq $\mathrm{ft}$ because it has a reduced infiltration rate resulting from sedimentation.

Other.-Recharge from precipitation was not modeled because, during drought periods, which cause extremely low flow in the stream, the water table declines below the root zone; therefore, precipitation entering the ground at the well field is retained in the soil root zone and has little or no opportunity to recharge the aquifer. Accordingly, no significant evapotranspiration occurs, because the water level in the well field is below the root zone of the crops.

\section{RESULTS AND CONCLUSIONS}

During the 2-year period modeled, 10,800 million gallons of water was withdrawn, of which 6,860 gallons came from aquifer storage, 3,610 million gallons was diverted from streamflow, and 324 million gallons was salvaged water that would have been discharged across the southeast boundary of the aquifer.

Figure 16 shows the rates of flow in the system. As in figure 15 the area between the pumping curve and the zero ordinate is proportional to volume pumped. This area is equal to the sum of the

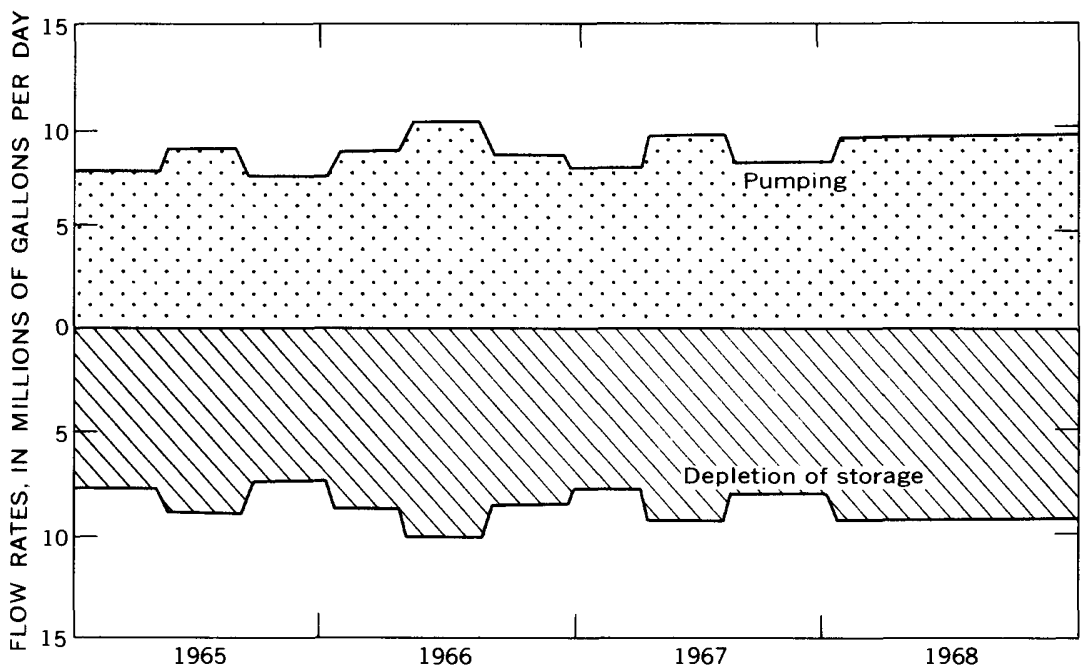

Figure 15.-Flow rates used for the analog-model solution of the storagedepletion problem. 


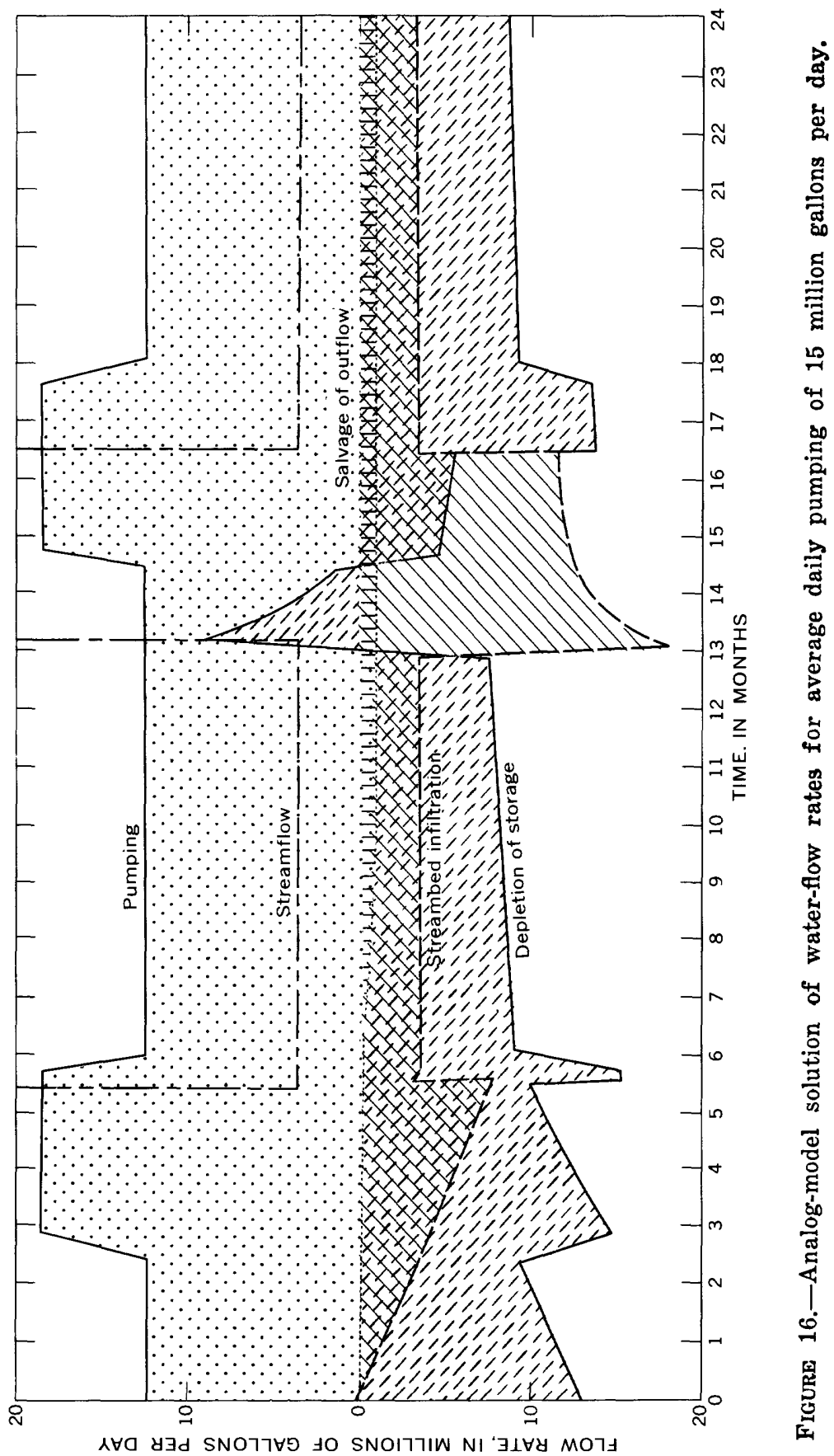


areas between the zero ordinate and each of the three curves (depletion of storage, streambed infiltration, salvage of outflow) below the zero ordinate.

Plate $1 C$ shows the water-level declines and the location of the wells. The predicted demands could be met by the well field as modeled, assuming that a well would not fail until the saturated thickness near the well was reduced to less than 10 feet. Optimum well spacing would have reduced the severity of drawdown in certain areas.

\section{EIGHTEEN MILLION GALLONS PER DAY PUMPING}

PROBLEM

Because of the predicted increase in water demand by Sioux Falls in future years, an enlarged well field with an average daily pumping rate of $18 \mathrm{mgd}$ was tested under adverse hydrologic conditions. An analog-model solution was obtained by using the modeling conditions listed below:

Pumping rate.-The pumping rate was modeled at $18 \mathrm{mgd}$. The monthly distribution of pumping was the same as in the previous problem. Nineteen additional wells, as shown in Plate $1 D$, were modeled to meet the maximum-day capacity of $40 \mathrm{mgd}$ of the expanded well field.

The aquifer, stream, streambed, and other hydrologic features.The aquifer, stream, and the streambed were modeled as in the previous problem. As in the previous problem, no other sources of recharge or discharge are considered.

\section{RESULTS AND CONCLUSIONS}

During the 2 years modeled, 12,900 million gallons of water was pumped, of which 8,480 million gallons came from storage, 3,970 million gallons was diverted from streamflow, and 430 million gallons was salvaged water that would have been discharged from the aquifer at the southeast boundary. Plate $1 D$ shows that in the northern end of the well-field drawdowns in excess of 8 feet did not occur except near a few wells. Excessive drawdown at these wells could have been reduced by increasing the number of wells and correspondingly decreasing the quantity of water pumped from each.

The rates of water movement are shown in figure 17.

MAXIMUM AVERAGE DAILY PUMPING

PROBLEM

To obtain an estimate of the maximum average daily pumping rate that the aquifer could sustain under adverse hydrologic con- 
ditions, the aquifer was modeled with the well field encompassing the entire aquifer.

Analysis of the results of the two previous analog-model solutions indicates that smaller rates of pumping per well would reduce the excessive drawdowns near some wells.

The spacing of wells along the stream is important because under normal conditions most of the water pumped is water that was lost from the stream to the aquifer. An estimate of the minimum distance $(L)$ between wells along the stream was calculated by

$$
L=\frac{Q}{w p} .
$$

At a pumping rate of $0.504 \mathrm{mgd}$, a streambed width of 100 feet, a depth of 1 foot, and an infiltration rate of $6.0 \mathrm{gpd}$ per sq ft the spacing is

$$
L=\frac{0.504 \mathrm{mgd}}{100 \mathrm{ft} \times 1 \mathrm{ft} \times 6.0 \mathrm{gpd} \text { per sq ft }}=835 \text { feet. }
$$

However, not all the water in an aquifer can be removed by pumping; thus, well spacings greater than 835 feet are required. A value of 1,200 feet was used as a guide in spacing wells for the analog-model problem. In addition to the wells spaced along the river, other wells in the model were located away from the stream to withdraw water from storage. An analog-model solution was obtained by using the modeling conditions listed below:

Pumping rate.-Using the spacing guide given above, 61 wells, in addition to those of the January 1, 1969 well field, were modeled. Assuming the capacity of a properly designed well as 0.504 mgd, the maximum-day rate modeled for the 61 additional wells was 61 times 0.504 or $30.8 \mathrm{mgd}$.

The January 1, 1969, well field was assumed to be producing at a maximum rate of $10.4 \mathrm{mgd}$ with a maximum-day rate of 27.0 mgd. The expanded well field as modeled had a maximum-day rate of $27.0 \mathrm{mgd}$ plus 30.8 , or $57.8 \mathrm{mgd}$.

The average daily rate for the 61 additional wells was $30.8 \mathrm{mgd}$ divided by the ratio of the maximum-day rate to the average day rate, or $13.7 \mathrm{mgd}$. The average daily rate for the expanded well field was $13.7 \mathrm{mgd}$ plus 10.4 , or $24.1 \mathrm{mgd}$.

Monthly distribution of pumping was the same as for previous problems. (See table 4).

The aquifer, stream, streambed, and other hydrologic features.-The monthly distribution of flow in the stream and the 


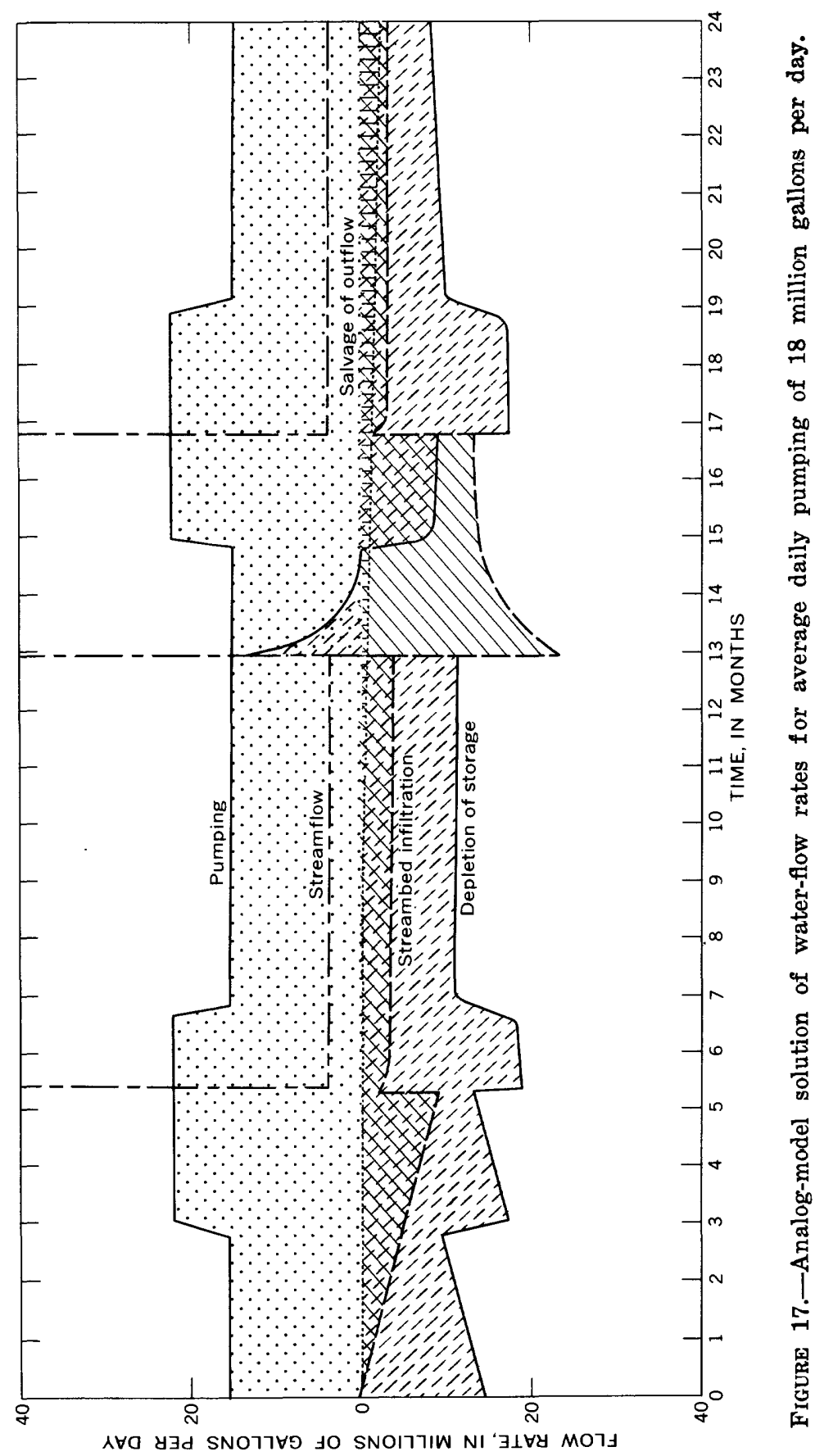


streambed and the aquifer were modeled as in the previous problem. No other hydrologic features were modeled.

RESULTS AND CONCLUSIONS

The analog-model results showed that during the 2 years modeled, 17,900 million gallons of water was pumped, of which 12,800 million gallons came from storage, 4,800 million gallons was intercepted streamflow, and 280 million gallons was salvaged water which would have been discharged across the southeast boundary. The model rates of water flow are shown in figure 18 . The change of water level and the well locations are shown in plate $1 E$. Drawdowns are excessive at and near some wells. Better spacing of wells probably would have eliminated the excessive drawdowns at some locations. However, plate $1 E$ indicates that the maximum sustainable average daily yield under the modeled conditions is less than $24 \mathrm{mgd}$.

\section{THE DIGITAL MODEL}

The digital model is a mathematical formulation, designed such that it can be solved on a digital computer, of flow in a porous medium. The computer program for the digital model was written in FORTRAN IV for the IBM 360 system. The model is capable of simulating the response of an unconfined aquifer to the pumping of one or more wells. The aquifer may be irregular in shape and nonhomogeneous and may be receiving infiltration from lakes, streams, and so forth (Pinder, 1970).

The finite-difference equations used in the digital model of nonsteady flow of a compressible fluid in an elastic nonhomogeneous porous medium have been described by Pinder and Bredehoeft (1968).

\section{SOLUTION OF MODEL PROBLEMS}

The storage-depletion problem was solved by use of a digital model of the aquifer under water-table conditions. Results from the digital model were compared with the corrected results from the analog.

\section{STORAGE DEPLETION}

PROBLEM

A study of the aquifer as the only element in the hydrologic system is useful in evaluating the relative importance of the aqui- 


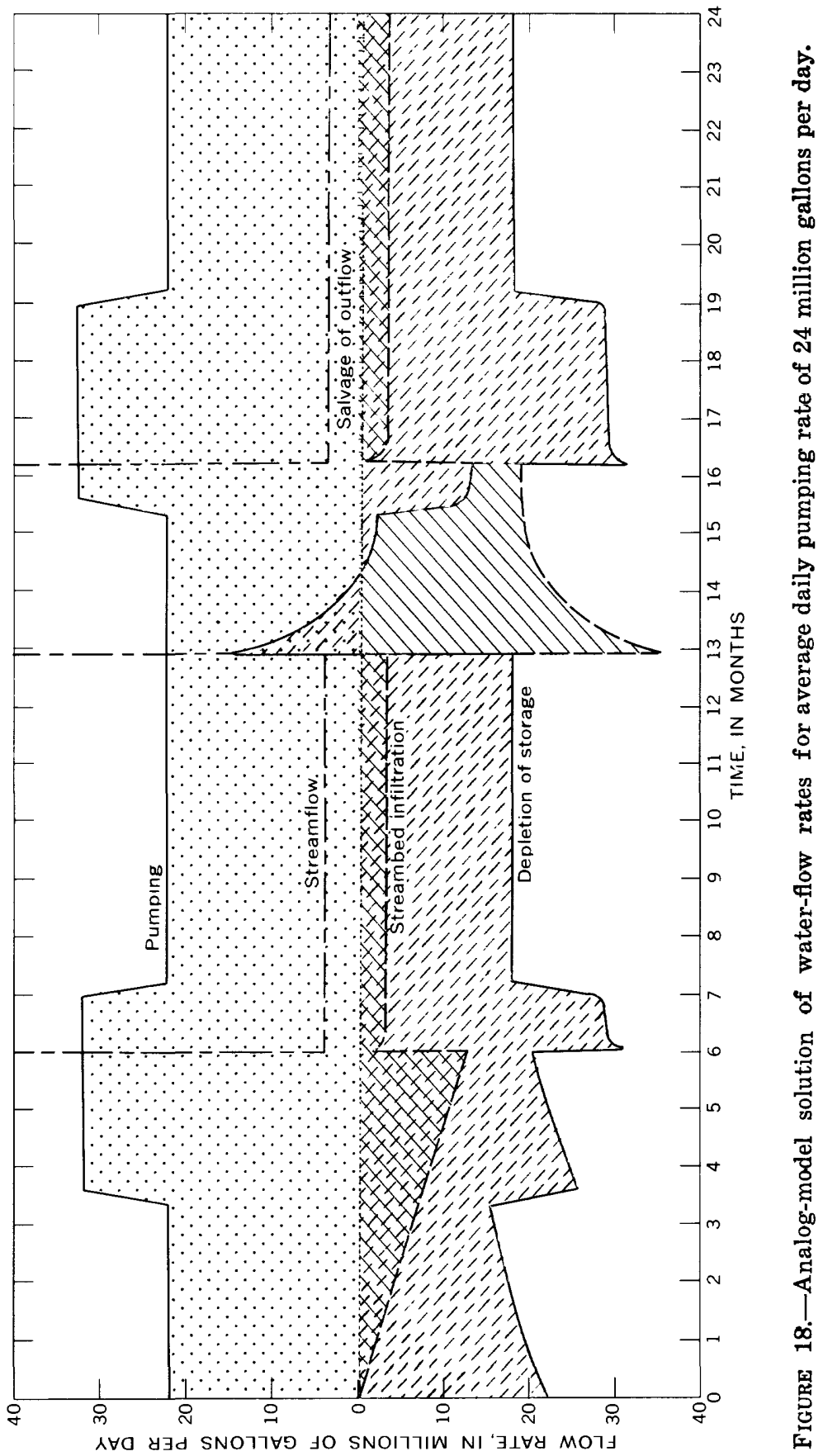


fer as a water supply. To study the aquifer in this manner it is assumed that all water pumped is taken from storage within the aquifer (storage depletion). A digital-model solution was obtained by using the modeling conditions listed below:

Pumping rate.-Model pumping rate of $9.9 \mathrm{mgd}$, the average rate for the period January 1965 through December 1968, was used.

Aquifer.-The aquifer was modeled with the transmissivities shown in plate $1 A$ and a storage coefficient of 0.20 . Impermeable boundaries were modeled as shown in plate $1 A$. Because drawdowns do not extend far beyond the well field, only that part of the aquifer affected was modeled.

Stream, streambed, and other hydrologic features.-The streambed and streamflow were not modeled. Neither recharge from precipitation nor discharge by evapotranspiration were modeled.

RESULTS AND CONCLUSIONS

Plate $1 F$ shows the decline of water levels at the end of a 1-year pumping period. The close agreement of the corrected drawdowns from the analog model (pl. $1 B$ ) as compared to drawdowns obtained from the digital model indicates that either model can be successfully used to model an aquifer under water-table conditions within the stated limitations.

If it is assumed that a well fails when the water table is lowered to within 10 feet of the base of the aquifer, no wells would have failed during the first year of pumping.

\section{QUALITY OF WATER}

The suitability of water for a given use is determined by its chemical and physical properties. Water suitable for one use may not be suitable for another. Some of the factors that affect the chemical and physical properties of water in the Sioux Falls area are climate, geology, topography, and man's activities, such as waste disposal, modification of drainage, and irrigation.

Some of the chemical constituents and physical properties that are measured to evaluate water for domestic use are given in table 5. The recommended limits of concentrations (U.S. Public Health Service, 1962) of these constituents of water for domestic use are also included in the table. The water from the vicinity of the Sioux Falls well field exceeds the recommended limit for dissolved solids and is within the limit for chlorides. Some of the water exceeds the limit for sulfates. 
TABLE 5.-Significance for domestic use of common chemical constituents and physical properties of water

\begin{tabular}{cc}
\hline $\begin{array}{c}\text { Constituent or } \\
\text { physical property }\end{array}$ & Source or cause \\
\hline $\begin{array}{c}\text { Calcium (Ca) } \\
\text { and magnesium } \\
(\mathrm{Mg}) .\end{array}$ & $\begin{array}{c}\text { Dissolved from practi- } \\
\text { cally all rocks and } \\
\text { soils, but especially } \\
\text { from limestone, dolo- } \\
\text { mite, gypsum, and } \\
\text { gypsiferous shale. }\end{array}$ \\
$\begin{array}{c}\text { Sodium (Na) and } \\
\text { potassium (K). }\end{array}$ & $\begin{array}{c}\text { Dissolved from prac- } \\
\text { tically all rocks and } \\
\text { soils. Found also in }\end{array}$ \\
& sewage, industrial \\
& waste, and waste \\
& brines. \\
& \\
Bicarbonate & action of carbon dioxide \\
$\left(\mathrm{HCO}_{3}\right)$ and & in water on carbonate \\
carbonate & rocks and soil mate- \\
$\left(\mathrm{CO}_{3}\right)$. & rials such as limestone \\
& and dolomite.
\end{tabular}

Sulfate $\left(\mathrm{SO}_{4}\right)$ _- Dissolved from rocks and soils containing gypsum, iron sulfides, and other sulfur compounds. Uusally present in drainage from mines and in some industrial wastes.

Chloride (Cl) _-_ Dissolved from rocks and soils. Present in sewage and found in large amounts in waste brines and some other industrial wastes.

Causes most of the hardness and scale-forming properties of water; soap consuming. (See hardness.)

Large concentrations, in combination with chloride, give a salty taste. Moderate concentrations have little effect on the usefulness of water for most purposes. Sodium salts may cause foaming in steam boilers.

Bicarbonate and carbonate produce alkalinity. Bicarbonate of calcium and magnesium decompose in steam boilers and hot water facilities to form scale and release corrosive carbon dioxide gas. In combination with calcium and magnesium cause carbonate hardness.

Sulfate in water containing calcium forms hard scale in steam boilers. In large concentrations, sulfate in combination with other ions gives a bitter taste to water and may cause a laxative effect. Federal drinking water standards recommend that sulfate concentration should not exceed 250 $\mathrm{mg} / \mathrm{l}$.

Chloride in large concentrations and in combination with sodium gives salty taste to drinking water and increases the corrosiveness of water. Federal drinking water standards recommend that the chloride concentrations should not exceed $250 \mathrm{mg} / \mathrm{l}$. 
TABLE 5.-Significance for domestic use of common chemical constitucnts and physical properties of water-Continued

\begin{tabular}{|c|c|c|}
\hline $\begin{array}{c}\text { Constituent or } \\
\text { physical property }\end{array}$ & Source or cause & Significance \\
\hline Nitrate $\left(\mathrm{NO}_{3}\right)$ & $\begin{array}{l}\text { Decaying organic mat- } \\
\text { ter, sewage, and ni- } \\
\text { trates in soil and } \\
\text { fertilizer. }\end{array}$ & $\begin{array}{l}\text { Concentrations much } \\
\text { greater than the local } \\
\text { average may suggest } \\
\text { pollution. More than } \\
\text { about } 45 \mathrm{mg} / 1 \text { nitrate } \\
\text { may cause methemo- } \\
\text { globinemia in infants, } \\
\text { sometimes fatal. Water } \\
\text { of high nitrate con- } \\
\text { centration should not } \\
\text { be used in baby feeding. }\end{array}$ \\
\hline Dissolved solids _- & $\begin{array}{l}\text { Chiefly mineral con- } \\
\text { stituents dissolved } \\
\text { from rocks and soils. } \\
\text { Includes any organic } \\
\text { matter. }\end{array}$ & $\begin{array}{l}\text { Water with large con- } \\
\text { centrations of dissolved } \\
\text { solids often has an } \\
\text { unpleasant taste. Fed- } \\
\text { eral drinking water } \\
\text { standards recommend } \\
\text { that the dissolved } \\
\text { solids should not ex- } \\
\text { ceed } 500 \mathrm{mg} / 1 \text {. }\end{array}$ \\
\hline $\begin{array}{l}\text { Hardness as } \\
\mathrm{CaCO}_{3} .\end{array}$ & $\begin{array}{l}\text { In most waters nearly } \\
\text { all the hardness is } \\
\text { due to calcium and } \\
\text { magnesium. Metallic } \\
\text { cations except alkali } \\
\text { metals also cause } \\
\text { hardness. }\end{array}$ & $\begin{array}{l}\text { Consumes soap before a } \\
\text { lather will form. De- } \\
\text { posits soap curd on } \\
\text { bathtubs. Hard water } \\
\text { forms scale in boilers, } \\
\text { water heaters, and } \\
\text { pipes. Waters of hard- } \\
\text { ness up to } 60 \mathrm{mg} / 1 \\
\text { are considered soft; } 61 \\
\text { to } 120 \mathrm{mg} / 1 \text {, moder- } \\
\text { ately hard; } 121 \text { to } 200 \\
\text { mg } / 1 \text {, hard; more than } \\
200 \mathrm{mg} / 1 \text {, very hard. }\end{array}$ \\
\hline $\begin{array}{l}\text { Specific con- } \\
\text { ductance. }\end{array}$ & $\begin{array}{l}\text { Mineral concentration } \\
\text { in the water. }\end{array}$ & $\begin{array}{l}\text { Specific electrical con- } \\
\text { ductance }(E C) \text { is a } \\
\text { measure of the ability } \\
\text { of the water to conduct } \\
\text { an electric current. } \\
\text { Varies with tempera- } \\
\text { ture, concentration, } \\
\text { and degree of ioniza- } \\
\text { tion of the constituents. }\end{array}$ \\
\hline $\begin{array}{l}\text { Hydrogen ion } \\
\text { concentration } \\
\text { (pH). }\end{array}$ & $\begin{array}{l}\text { Acids, acid-generating } \\
\text { salts, and dissolved } \\
\text { carbon dioxide lower } \\
\text { the pH; carbonates, } \\
\text { bicarbonates, hydroxides, } \\
\text { phosphates, silicates, } \\
\text { and borates raise } \\
\text { the pH. }\end{array}$ & $\begin{array}{l}\text { A pH of } 7.0 \text { indicates } \\
\text { neutral solution. Values } \\
\text { higher than } 7.0 \text { indi- } \\
\text { cate increasing alka- } \\
\text { linity; values lower } \\
\text { than } 7.0 \text { indicate in- } \\
\text { creasing acidity. pH } \\
\text { is a measure of the } \\
\text { activity of the hydrogen } \\
\text { ions, corrosiveness of } \\
\text { water generally in- } \\
\text { creases with decreas- } \\
\text { ing pH. However, ex- } \\
\text { cessively alkaline waters } \\
\text { may also attack metals. }\end{array}$ \\
\hline
\end{tabular}


All concentrations except $\mathrm{pH}$ are reported in milligrams per liter $(\mathrm{mg} / \mathrm{l})$. Units of milligrams per liter are very nearly equivalent to units of parts per million ( $\mathrm{ppm}$ ) and are regarded as equivalent in this report. Electrical conductivity is reported in micromhos per centimeter. Temperature is reported in degrees Celsius (centigrade).

Electrical conductance or $E C$ is a function of the degree of mineralization of water. The $E C$ is a parameter that describes the ease of electrical flow in the water and is easily measured with a conductance meter.

\section{MEASUREMENTS OF CONDUCTIVITY AND TEMPERATURE}

Temperature and conductivity measurements of the water were made in the Sioux Falls well field during 1968 to aid in defining the relationship between ground water and surface water.

Figure 19 shows the conductivity of the water in the well field on August 30,1968. The conductivity of the water in the river on that date was about 730 micromhos per centimeter. Water from wells along the river has a conductance similar to the conductance of water in the river. The higher conductivity of the water in the center of the well field, away from the river, indicates that water in the aquifer in this region is more mineralized.

Figure 20 shows that water from well 11 near the center of the well field is of nearly uniform conductivity during the entire year. Water from well 20, located near the river, has a typically lower but a more variable conductivity than well 11 because of the influence of infiltrated river water.

In general, the conductivity of the river water varies inversely with the flow. For example, in the winter months most of the water consists of the more mineralized base flow from the aquifer and consequently, the river water is quite mineralized. At other times, especially in the spring months, most of the water consists of less-mineralized direct runoff, which results from snowmelt or rainfall. Figure 20 shows the conductivity of the water in the Big Sioux River.

Figure 21 shows the temperature variation of the ground water in the aquifer. For comparison, the average temperature of the water in the river was about $16^{\circ} \mathrm{C}$ from September $1-7,1968$. The higher temperature of water from wells near the river probably shows the effect of the warmer river water as it infiltrates the streambed and moves into the aquifer. The lower temperatures of the water from wells in the center of the well field indicate the small temperature effect of streambed infiltration distant from the stream. 
EXPLANATION $0^{950}$

Well, and electrical conductivity in micromhos per centimeter

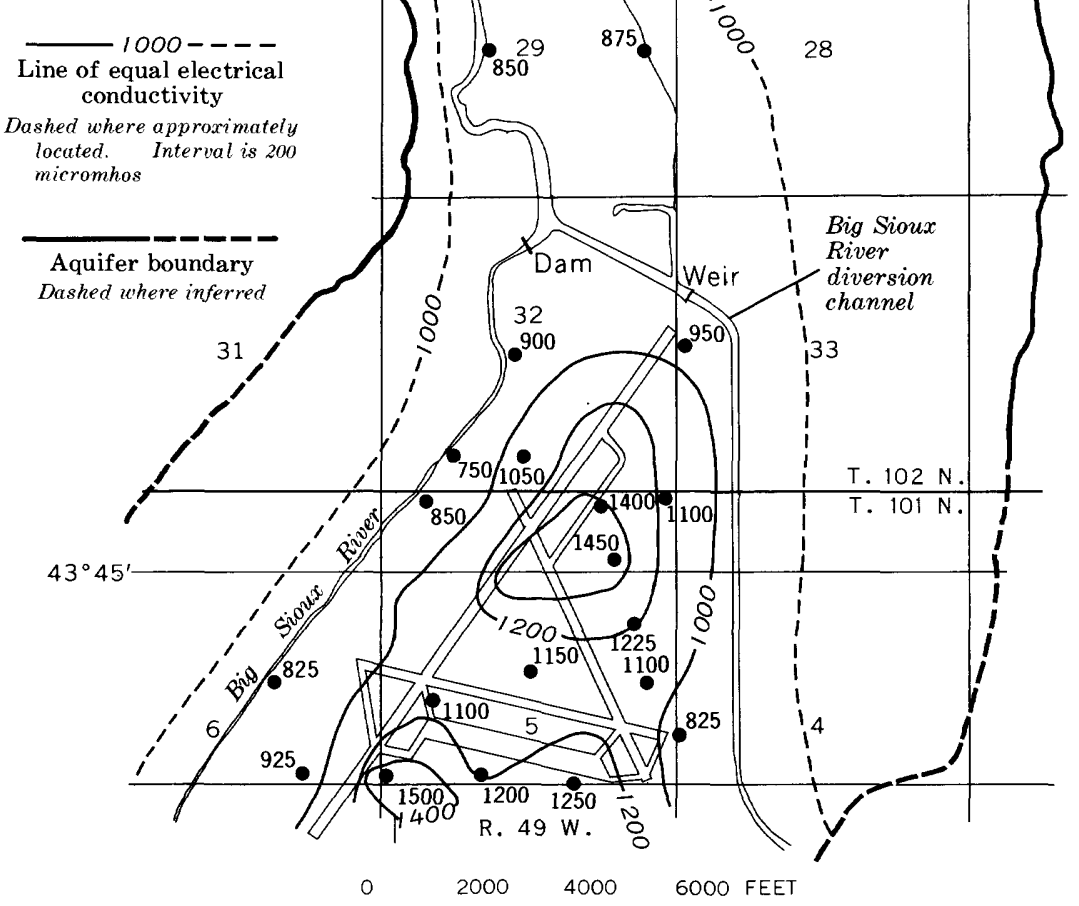

Figure 19.-Electrical conductivity of the water in the Sioux Falls well field, August 30, 1968.

Figure 22 shows the large temperature variation of the water in the Big Sioux River and the minor temperature fluctuations of the water 2,500 feet from the river in well 11 . The water temperature in well 20 is a result of many factors; however, it appears to vary, at least partially, in response to the variation of the temperature of the water infiltrating from the river. 


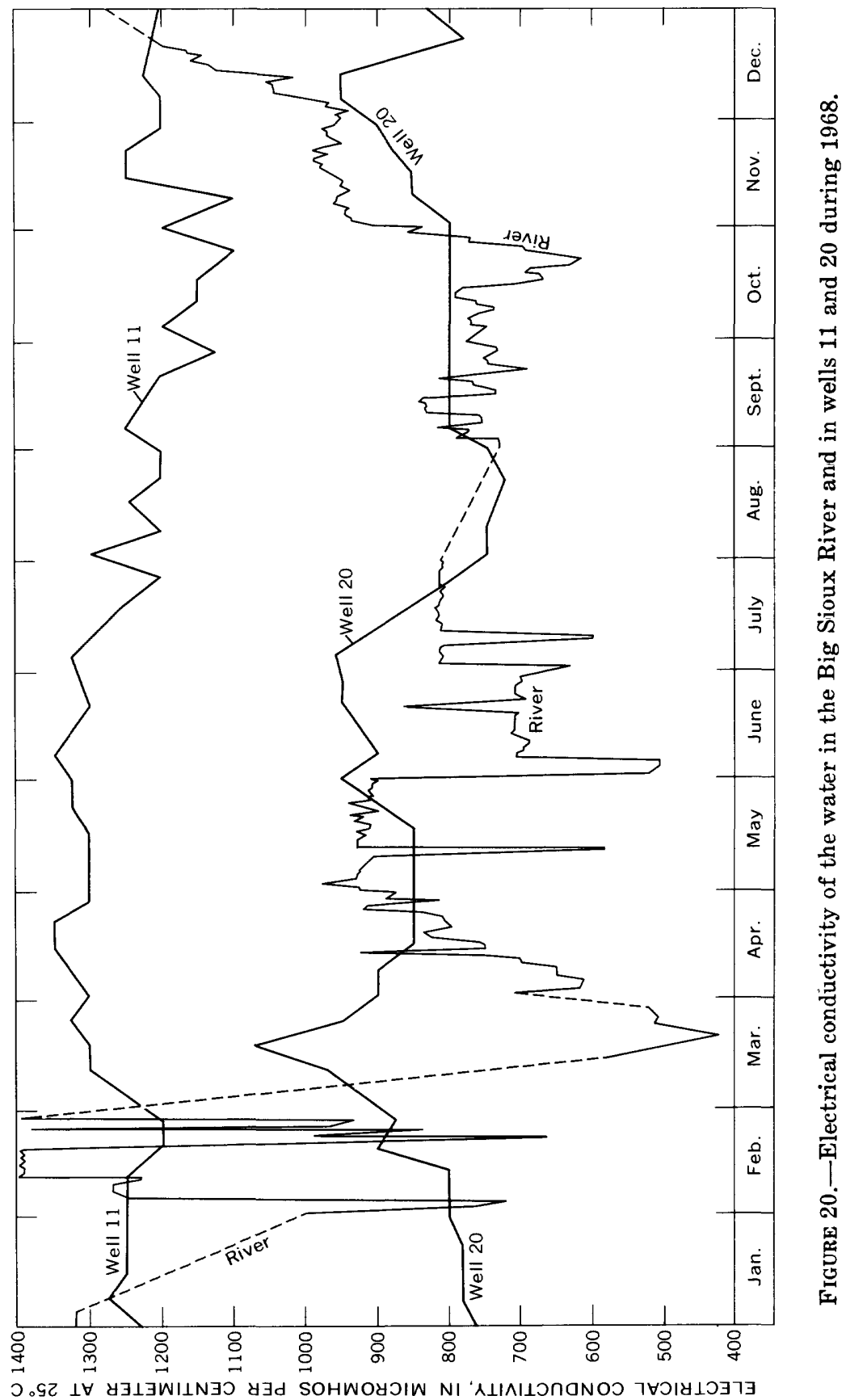




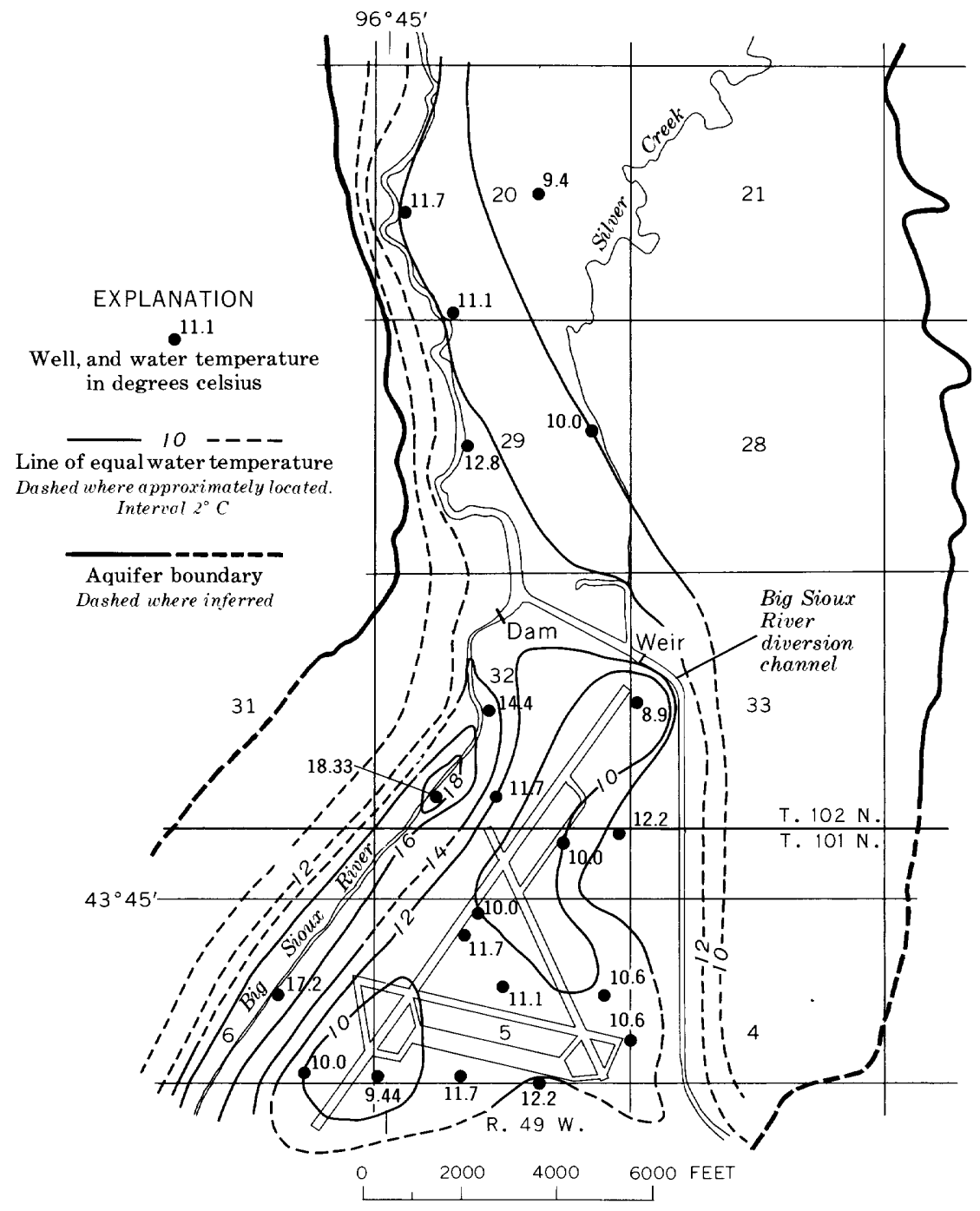

Figure 21.-Temperature of the water in the Sioux Falls well field, August 30, 1968.

\section{CHEMICAL CONSTITUENTS OF GROUND WATER AND SURFACE WATER}

Table 6 lists chemical constituents of water from several different sources on May 8, 1968. The chemical constituents of the treated water are listed for comparison. The table shows that surface water from the river and the diversion channel is slightly 


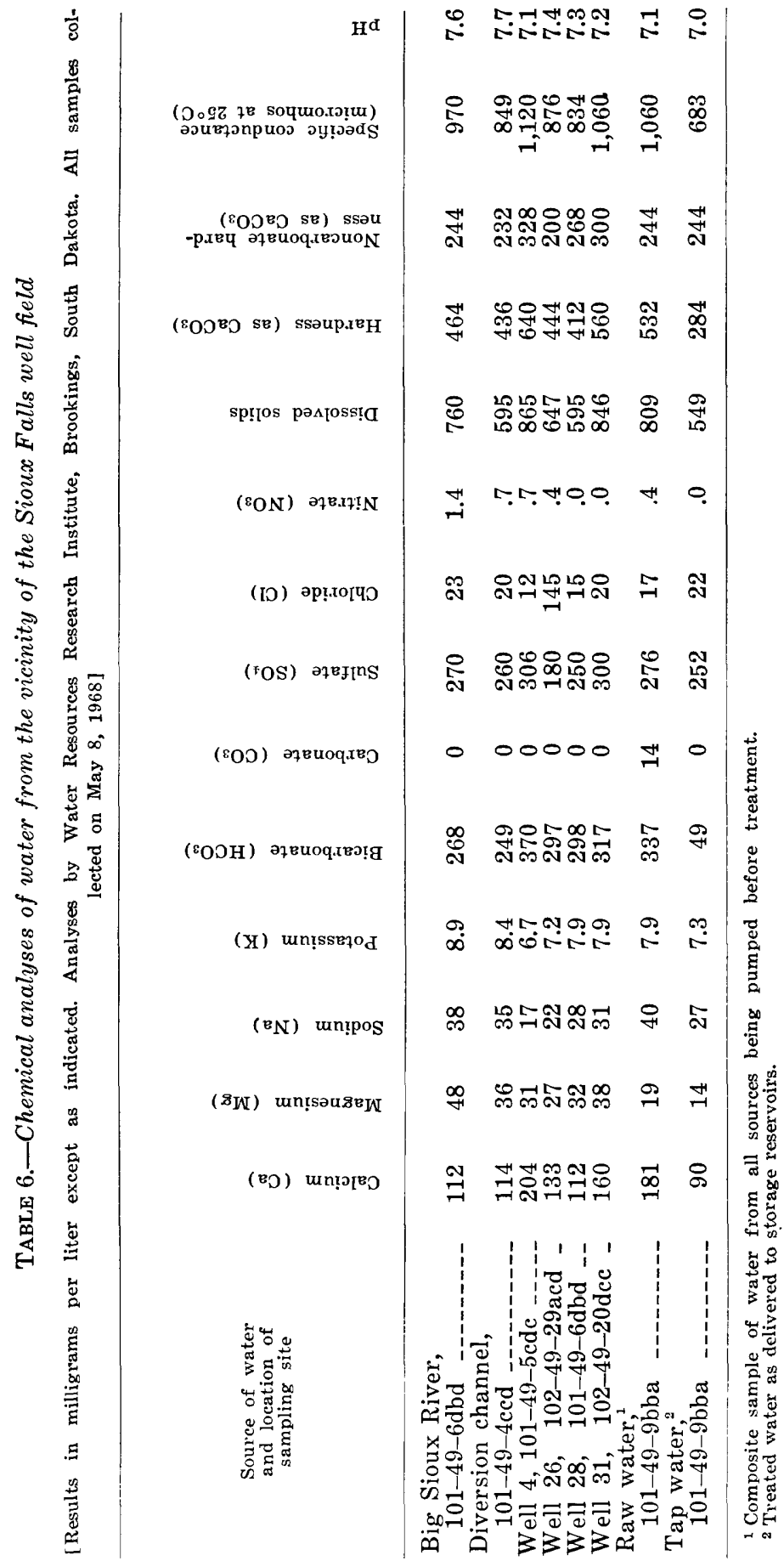


softer than water from wells 4 and 26, which are located away from the river. Table 6 also shows that treatment of raw water by the city of Sioux Falls reduced both the hardness and the dissolved-solids content.

Although, in general, the differences between the quality of water in the river and water in the aquifer at the well field are not large, the differences necessitate some variations in methods of treating the water. Well water pumped largely from aquifer storage is more mineralized and costs more to treat than water taken -directly from the river. Unfortunately, objectionable tastes and odors are often associated with the river water. Water from wells located near the river has no objectionable odor or taste and is relatively economical to treat.

\section{SUMMARY}

The major sources of water in the Big Sioux River valley near the city of Sioux Falls are the Big Sioux River and the aquifer underlying the flood plain. The river and the aquifer are closely related in the hydrologic system and must be developed conjunctively.

The Big Sioux River has an average discharge of $246 \mathrm{cfs}$; however, it is subject to periods of extremely low flow. The lowest recorded discharge is $0.1 \mathrm{cfs}$. The 2-year period with the lowest flow was from February 1958 to January 1960. Flooding above bankfull stage, which results in additional recharge to the aquifer, has a recurrence interval of 2.3 years. Considerable water is stored in the river basin, as shown in the flow-duration curve.

The aquifer, which is a glacial outwash deposit consisting of permeable sand, sand and gravel, and some boulders, lies almost entirely beneath the flood plain. It has an area of about 33 square miles and commonly has a saturated thickness of 30 feet or less.

An analog-model solution indicates that with no recharge from precipitation and with flow equivalent to the 2-year period of lowest recorded streamflow in the Big Sioux River, the maximum sustained average daily yield of ground water is less than $24 \mathrm{mgd}$. This value is primarily dependent upon aquifer transmissivity and storage. However, under normal conditions the sustained yield is primarily dependent on the availability of water in the river and the hydraulic conductivity of the streambed.

The rate of streamflow loss to the aquifer is dependent on hydraulic conductivity of the streambed, the hydraulic head, and the viscosity of the water in the stream. Aquifer tests and stream-loss 


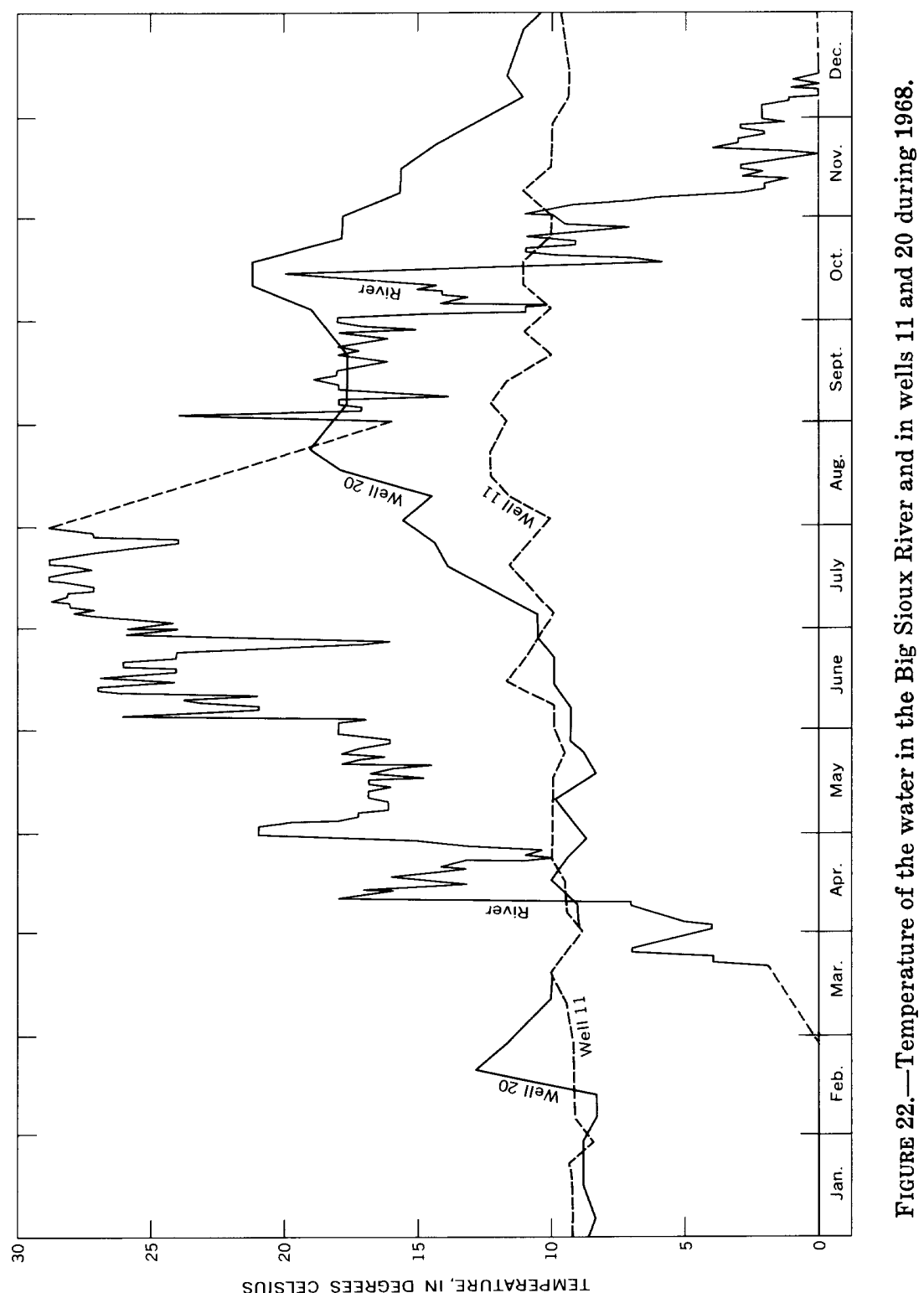


measurements indicate rates of streambed infiltration of about 6 gpd per sq ft.

Electric logging of the backwater area indicated that silts and clays were the predominant type of sediment. Laboratory analyses of sediment samples of the backwater area behind the weir and the dam indicate vertical infiltration rates of about $0.3 \mathrm{gpd}$ per sq ft.

Removal of the sediment in the backwater area behind the dam and the weir would increase the recharge in this area of the well field. The rise of the water level resulting from the removal of the sediment from a small area of the diversion channel was demonstrated by a pilot program of sediment removal by dredging.

A problem involving only withdrawal of water from the aquifer by pumping was solved mathematically using a digital model. The digital-model solution was compared with the analog-model solution that had been corrected to represent water-table conditions. Close agreement of the two solutions indicates that either method yields satisfactory results for the conditions modeled. Both solutions show that the aquifer would be able to sustain pumping for more than 1 year at approximately 9 to $10 \mathrm{mgd}$, the 1965-68 rate.

Water from the river generally is less mineralized than the ground water. Also, ground water in the aquifer generally is more mineralized in areas distant from the Big Sioux River.

Surface water from the Big Sioux River is less costly to treat than ground water because it is less mineralized and is slightly softer; however, river water often has an undesirable taste and odor that are difficult to remove. Ground water from wells near the river is similar in quality to the river water but does not have objectionable odors or tastes, and it is relatively easy to treat.

Wells located near the river efficiently induce recharge from it, whereas wells distant from the river withdraw most water from aquifer storage.

\section{SELECTED REFERENCES}

Ackroyd, E. A., 1967, Electric analog computers for hydrologic systems: South Dakota Acad. Sci. Proc., v. 46, p. 227-231.

- 1969, Streamflow regimen as applied to hydrologic systems analysis: South Dakota Acad. Sci. Proc., v. 48, p. 96-103.

Ellis, M. J., 1968, Basic hydrologic data, for a part of the Big Sioux drainage basin, eastern South Dakota: South Dakota Geol. Survey and South Dakota Water Resources Comm., Water Resources Rept. 5, $135 \mathrm{p}$. 
Ellis, M. J., Adolphson, D. G., and West, R. E., 1969, Hydrology of the Big Sioux drainage basin, eastern South Dakota: U.S. Geol. Survey Hydrol. Inv. Atlas 311 (with pamphlet text).

Jacob, C. E., 1944, Notes on determining permeability by pumping tests under water table conditions: U.S. Geol. Survey open-file report.

- 1950, Flow of ground water in Rouse, H., ed., Engineering Hydraulics: New York, John Wiley and Sons, p. 321-386.

Karplus, W. J., 1958, Analog simulation: New York, McGraw-Hill Book Co., $434 \mathrm{p}$.

Norris, S. E., and Fidler, R. E., 1969, Hydrogeology of the Scioto River Valley near Piketon, South-central Ohio: U.S. Geol. Survey Water-Supply Paper $1872,66 \mathrm{p}$.

Patten, E. P., Jr., 1965, Design, construction, and use of electric analog model, in Wood, L. A., and Gabrysch, R. K., Analog model study of ground water in the Houston district: Texas Water Comm. Bull. 6508, p. 41-103.

Pinder, G. F., 1970, An iterative digital model for aquifer evaluation: U.S. Geol. Survey open-file report, $24 \mathrm{p}$.

Pinder, G. F., and Bredehoeft, J. D., 1968, Application of digital computer for aquifer evaluation: Water Resources Research, v. 4, no. 5, p. 1069-1093.

Rakness, K. L., 1970, Analysis of flow variation of the Big Sioux River: unpub. master's thesis, South Dakota State Univ., Brookings, South Dakota, $89 \mathrm{p}$.

Ranney Water Systems, Inc., 1956a, Preliminary report on hydrogeological survey for city of Sioux Falls, South Dakota: 5 p.

1956b, Report on installation of horizontal laterals, well number 4, Sioux Falls, South Dakota: 12 p.

1957, Report on Ranney-collectors, wells 31,32 , and 33, for city of Sioux Falls, South Dakota: 33 p.

- 1961, Report on the hydrogeological survey diversion channel area, city of Sioux Falls, South Dakota: 21 p.

Rothrock, E. P., and Otton, E. G., 1947, Ground-water resources of the Sioux Falls area, South Dakota, Parts I and II: South Dakota Geol. Survey Rept. Inv. 56, 108 p.

Skibitzke, H. E., 1961, Electronic computer as an aid to the analysis of hydrologic problems: Gentbrugge, Belgium, International Assoc. Scientific Hydrology, Comm. Subterranean Waters, Pub. 52, p. 347-358.

Stallman, R. W., 1956, Numerical analysis of regional water levels to define aquifer hydrology: Am. Geophys. Union Trans., v. 37, no. 4, p. 451-460.

1963, Type curves for the solution of single boundary problems: U.S. Geol. Survey Water-Supply Paper 1545-C, p. 45-47.

Steece, F. V., 1959, Geology of the Sioux Falls quadrangle, South Dakota: South Dakota Geol. Survey Geol. quad. map and text.

Theis, C. V., 1941, The effect of a well on the flow of a nearby stream: Am. Geophys. Union Trans., v. 22, pt. 3, p. 734-738.

Tipton, M. J., 1959, Geology of the Dell Rapids quadrangle, South Dakota: South Dakota Geol. Survey Geol. quad. map and text.

U.S. Bureau of Reclamation, 1969, Reconnaissance report on Sioux Falls unit, South Dakota: Missouri-Ohio projects, Huron, S. Dak., 65 p.

U.S. Public Health Service, 1962, Drinking water standards: Public Health Service Pub. 956, 61 p. 
Vaughan, K. D., and Ackroyd, E. A., 1968, A preliminary report of a recently discovered aquifer at Sioux Falls, South Dakota: South Dakota Acad. Sci Proc., v. 47, p. 68-74.

Walton, W. C., and Ackroyd, E. A., 1966, Effects of induced streambed infiltration on water levels in wells during aquifer tests: Water Resources Research Center Univ. of Minn. Bull. $43 \mathrm{p}$.

* U.S. GOVERNMENT PRINTING OFFICE: $19730-543-576 / 15$ 


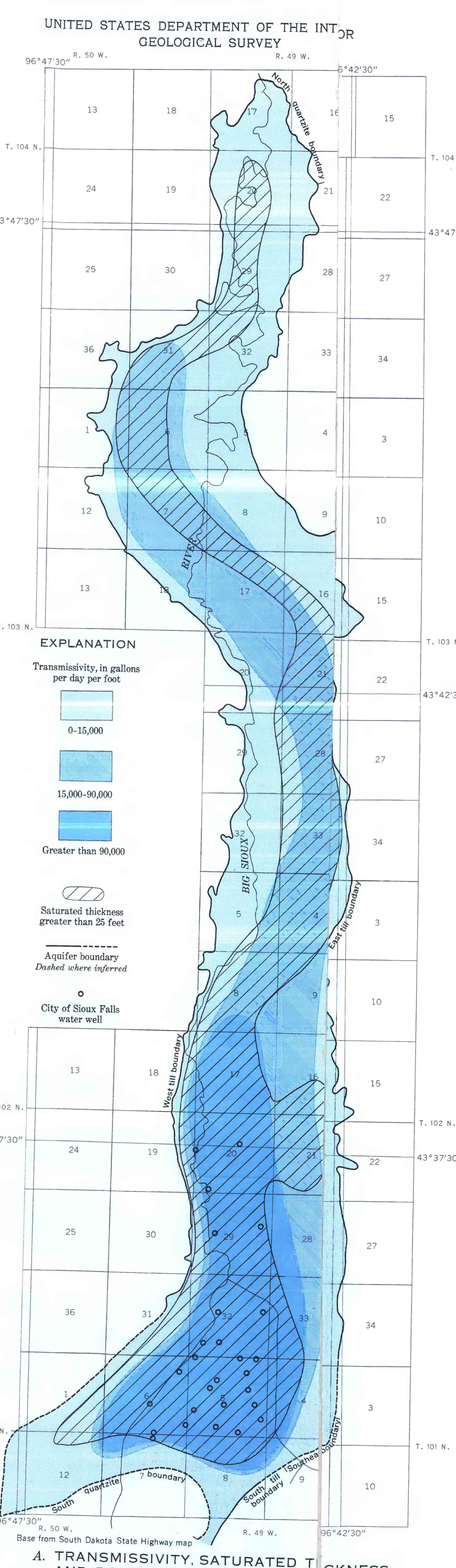

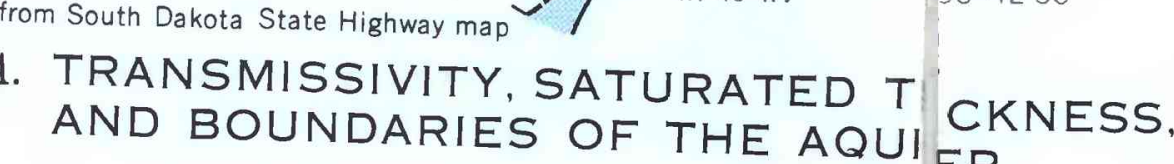
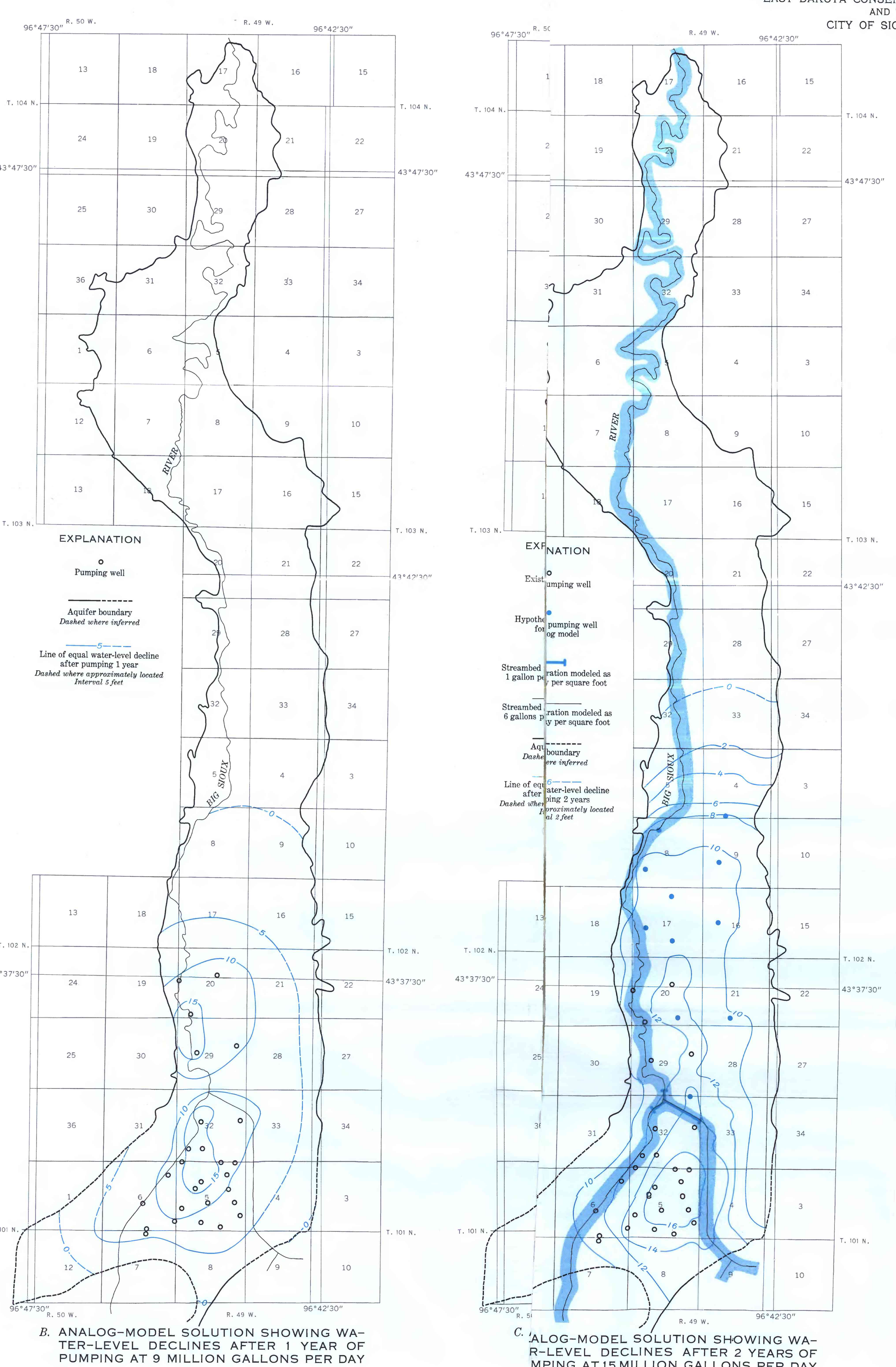

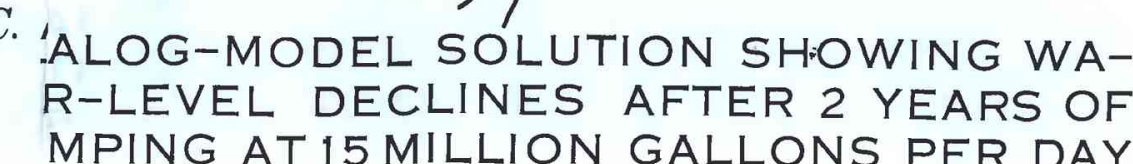

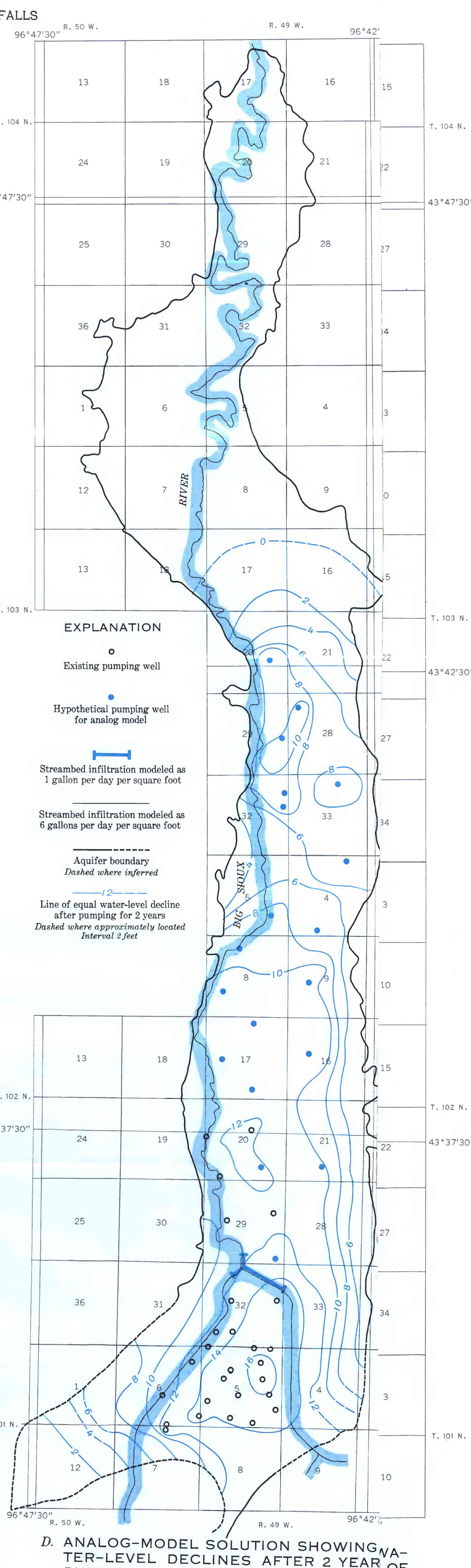

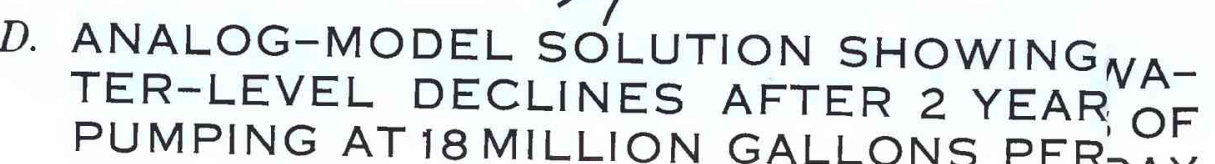

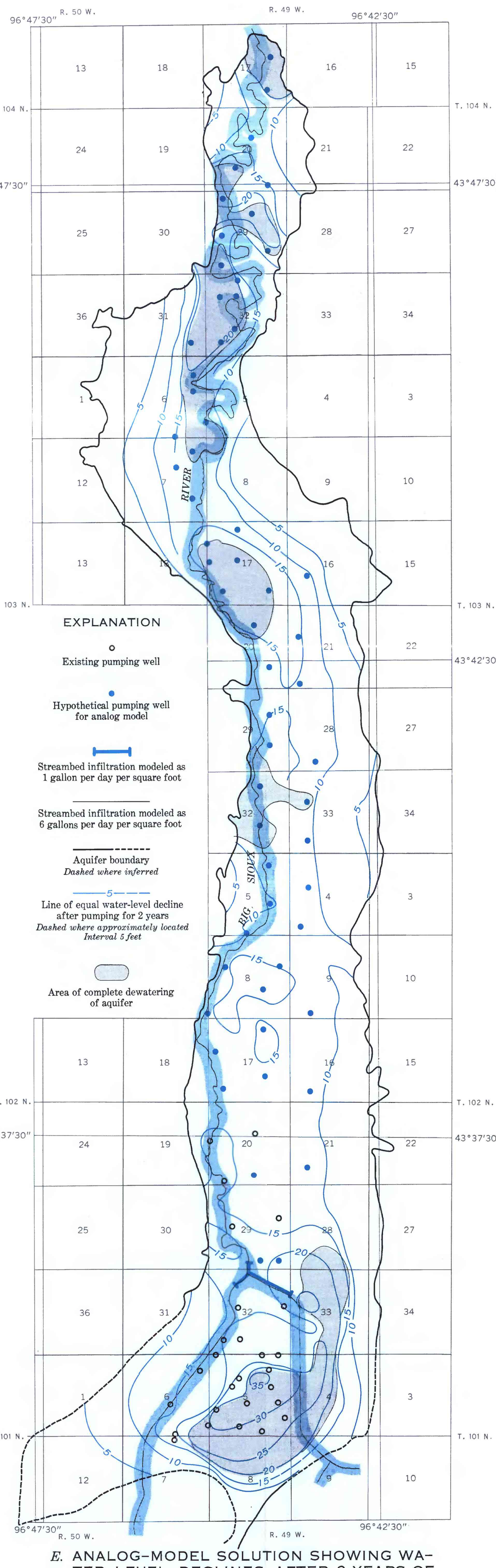

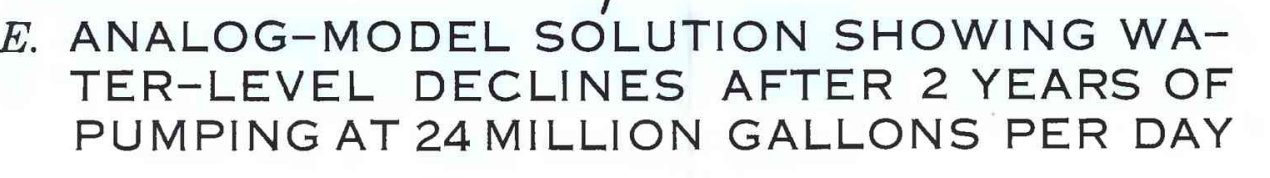

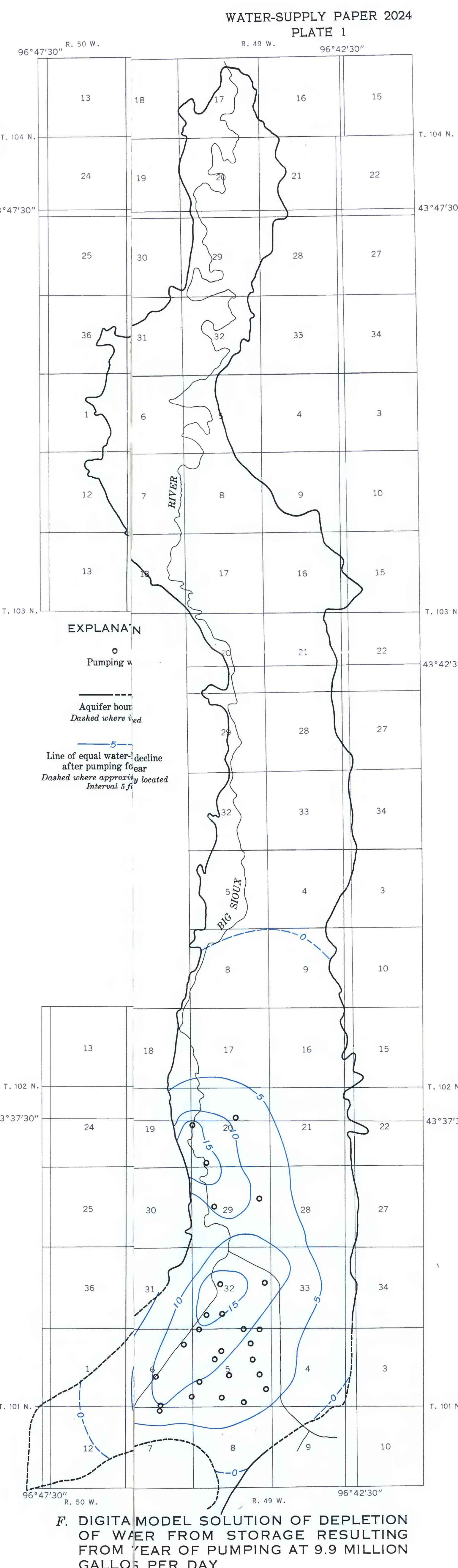

